\title{
Organic-Aggregate-Attached Bacteria in Aquatic Ecosystems: Abundance, Diversity, Community Dynamics and Function
}

\author{
Xiangming Tang ${ }^{1}$, Jianying Chao ${ }^{2}$, Dan Chen ${ }^{1}$, \\ Keqiang Shao ${ }^{1}$ and Guang Gao ${ }^{1}$ \\ ${ }^{1}$ State Key Laboratory of Lake Science and Environment, \\ Nanjing Institute of Geography and Limnology, Chinese Academy of Sciences, \\ ${ }^{2}$ Nanjing Institute of Environmental Science, \\ Ministry of Environmental Protection, \\ P.R. China
}

\section{Introduction}

Micro- and macroscopic aggregates are a ubiquitous and abundant component of aquatic ecosystems. The occurrence and ecological importance of macroscopic aggregates $(>500 \mu \mathrm{m}$, also known as marine snow) in the pelagic environment has been extensively studied for more than 30 years (Alldredge and Silver 1988, Grossart et al. 2007, Kiørboe and Jackson 2001, Smith et al. 1992, Silver et al. 1978). And several studies on macroscopic aggregates in deep lake and lotic ecosystems, known as lake snow and river snow, have been reported in recent years (Böckelmann et al. 2002, Grossart and Simon 1993, Grossart and Simon 1998). It has also been suggested that aggregates serve as transient microhabitats suitable for kinds of biogeochemical processes (Paerl and Prufert 1987, Azam and Richard 2001). Abundant of bacteria, rich in nutrients and high metabolic activity of attached microorganisms made the aggregates "hotspots" in energy fluxing, biogeochemical cycling and food web dynamics (Azam and Richard 2001, Caron et al. 1982, Paerl 1974, Simon et al. 2002, Grossart and Ploug 2000).

Compared with pelagic systems in which low hydrodynamic stress allows macroaggregates to form, microaggregates $(5-500 \mu \mathrm{m})$ dominate in shallow, turbid, and eutrophic systems, such as Lake Taihu (Tang et al. 2009). Lake Taihu, the third largest lake in China, has an area of 2,338 $\mathrm{km}^{2}$, and a catchment area of about $36,500 \mathrm{~km}^{2}$; its maximum length is $68.5 \mathrm{~km}$ and the maximum width is $56 \mathrm{~km}$ (Fig. 1). It's a typical shallow lake with the mean depth $<2 \mathrm{~m}$. In contrast to marine and deep lake systems, Taihu is more productive and it has significant horizontal environmental gradients from northwest to southeast. These gradients, in such parameters as trophic status, concentration of suspended particles, and concentration of Chlorophyll $a$, provide almost unique opportunities for revealing mechanisms that control the composition of bacterial communities within the lake (Tang et al. 2010). Moreover, winddriven sediment resuspension and intensive cyanobacterial blooms are two major ecological features of this lake (Qin 2008). However, while macroaggregates-attached microbial communities in marine, estuary, river, and deep lake systems have been well-characterized, 
little is known about the composition and diversity of the smaller organic-aggregateassociated bacterial communities (OABC), and the environmental factors which shape their dynamics, in large shallow eutrophic subtropical lakes.

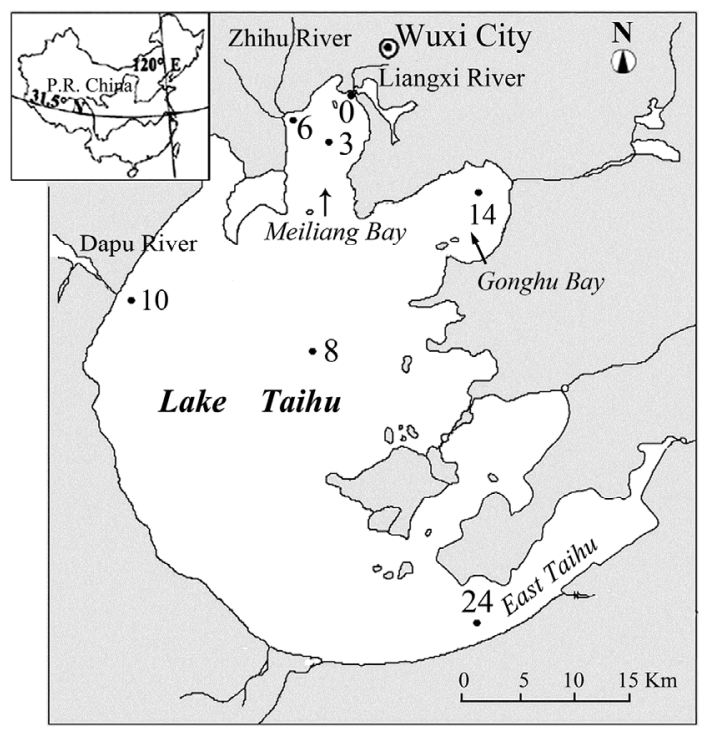

Fig. 1. Map of Lake Taihu and the sampling sites.

Based on terminal restriction fragment length polymorphism (T-RFLP) and 16S ribosomal ribonucleic acid (rRNA) gene clone libraries, we investigated the spatial and temporal heterogeneity of OABC in Lake Taihu during May 2006 to May 2008. Samples were collected at seven stations representing different trophic states and food web structures (Fig. 1.). Site 0 , Site 6 and Site 10 are located in highly eutrophic areas near the river mouth of Liangxi River, Zhihu River and Dapu River, respectively; the eutrophication is due to nitrogen and phosphorus from domestic and industrial wastewater discharged from the rivers. Site 3 is located in Meiliang Bay, which experiences intensive blooms of algae, dominated by Cyanobacteria, during summer and autumn. Site 8 is located in the open lake, where the water is less enriched with nitrogen and phosphorus but exposed to frequent wind mixing (Wu et al. 2007b). Site 14 is located in Gonghu Bay, a transition area from phytoplankton- to macrophyte- dominated lake habitats. Site 24 is located in East Taihu, which is characterized by submersed macrophyte communities and relatively low phytoplankton concentrations (Tang et al. 2010, Tang et al. 2009).

From the studies on the organic aggregates (OA)-attached bacteria in the large, shallow and eutrophic Lake Taihu, China, some new results which differed from pelagic ecosystems were found. This is a short review of the current understanding of the role of microorganisms attached to organic aggregates in aquatic ecosystems, the gaps in our knowledge and some suggestions of future directions. And this study is the first attempt to summarize the current research achievements on the abundance, diversity, community dynamics and function in different aquatic ecosystems. 


\section{The abundance of OA-attached bacteria}

\subsection{The abundance of OA-attached bacteria in different aquatic systems}

Bacteria have been found to be colonized on nearly all types of aggregates studied so far, including marine, lacustrine, and riverine macro- and microaggregates (Simon et al. 2002). Macroscopic organic aggregates is densely colonized by microbes, which are not uniformly distributed on aggregates but often form microcolonies (Simon et al. 2002 and references therein). Obviously, the nature of particles and their adsorption capacities determine the abundance of colonized bacteria (Berger et al. 1996). Due to different hydrodynamic conditions and heterogeneity of phytoplankton communities, aggregates in different aquatic systems differed in size and components. Hence, the abundance of attached bacteria and their relative proportion to total bacterial numbers in different systems varies greatly (Table 1).

In marine environments, numbers of attached bacteria on macroscopic organic aggregates (> $500 \mu \mathrm{m})$ have been documented since 1986. Densities of bacteria ranged from $1.25-1.69 \times$ $10^{6}$ cells per aggregate in Southern California Bight to $1.83-278 \times 10^{6}$ cells per aggregate in North Atlantic (Alldredge et al. 1986). On a giant aggregate, the density of bacteria reached to as high as $5.4 \times 10^{8}$ cells (Silver et al. 1998). However, the ratio of macroaggregatesattached bacteria to total bacteria of the surrounding water is relatively low. In most case, they constitute $<10 \%$ of total bacterial numbers (Table 1). On microaggregates, the percentage of attached bacteria is higher. For example, in a tidally affected coastal ecosystem located in German Wadden Sea, the particle-attached bacteria constituted proportions of 7$47 \%$ of total bacteria (Rink et al. 2008). Moreover, the abundance of attached bacteria varied with water depth. In NW Mediterranean Sea, they increased with water depth and reached the most abundant of $3.4 \times 10^{5}$ cells $\mathrm{ml}^{-1}$ in $80 \mathrm{~m}$ depth, accounting for $14 \%$ of the total bacteria (Ghiglione et al. 2007).

Natural lake snow aggregates were densely colonized by microbes (Table 1). In deep lakes, $0.002 \times 10^{6}$ to $23 \times 10^{6}$ bacteria per $\mathrm{ml}$ were counted in Lake Constance, a large mesotrophic freshwater lake in Central Europe (Schweitzer et al. 2001, Grossart and Simon 1993), and where transparent exopolymer particles (TEP) and Coomassie-stained particles (CSP) aggregates in Lake Aydat and Lake Pavin could carry similar orders of bacteria (Lemarchand et al. 2006).

The size of riverine aggregates is usually smaller than lake snow or marine snow (ZimmermannTimm et al. 2002 and references therein). However, the abundance of aggregate -attached bacteria is much higher than that in marine and deep lake systems. In Columbia River estuary, the numbers ranged from $0.1 \times 10^{6}$ to $12.6 \times 10^{6}$ cells $\mathrm{ml}^{-1}$, where enriched aggregates in River Elbe could carry much larger numbers, up to $120-250 \times 10^{6}$ cells ml $^{-1}$ (Böckelmann et al. 2000). In contrast to marine and deep lake systems, aggregates in riverine and estuarine systems can constitute as much as $90 \%$ of total bacterial numbers and production (Simon et al. 2002 and references therein; Table 1). In lab conditions, the abundance of aggregate-attached bacteria can reach to as high as $37.0 \times 10^{9}$ cells (ml agg.) $)^{-1}$ (Grossart et al. 2003a).

Based on a 25-month observations of OA and the attached bacteria in the large, shallow, eutrophic Lake Taihu, Tang (2009) revealed that the abundance of OA range from 1.3 to $23.5 \times 10^{5}$ ind. $\mathrm{ml}^{-1}$ (average $7.1 \times 10^{5}$ ind. $\mathrm{ml}^{-1}$ ), and most of them are microaggregates with a size of 10 200 $\mu \mathrm{m}$. Detrital and algal aggregates dominate in Lake Taihu. Furthermore, there are temporal and spatial dynamics of the origins and compositions of OA. The average abundance of OA-associated bacteria is $15.5 \times 10^{6}$ (range $3.6-32.4 \times 10^{6}$ ) cells ml-1, accounted for $53 \%$ (range $28.7-80.4 \%$ ) of the total bacteria. The mean number of bacteria per particle was much higher in Lake Taihu (25.6 bacteria particle-1) than in River Danube (8 bacteria 
particle $^{-1}$ ) (Berger et al. 1996). The abundance of OA-associated bacteria are related in OA, water temperature, total suspended solids (TSS), total phosphorus (TP) and Chl $a$. Results of scanning electron microscopy (SEM) and 4' 6-diamidino-2-phenylindole dihydrochloride (DAPI ) demonstrated that the abundance of OA-associated bacteria is much higher than that of in oceans and deep lakes, which indicates the ecological importance of OA in shallow lakes. Aggregate abundances are higher in lotic systems, such as in rivers and shallow eutrophic lakes, than in deep lakes and in the sea (see above) due to high resuspension rates (Zimmermann-Timm et al. 2002 and references therein).

Bacterial abundance on aggregates is initially driven by a balance between bacterial attachment and detachment (Kiørboe et al. 2002), and subsequently by bacterial growth on the particle surfaces. Previous study (Grossart et al. 2006) showed that percentages of aggregates-attached bacteria greatly changed over time. In addition to bacterial colonization and growth, predation may also affect bacterial abundance and community composition on macroaggregates (Kiørboe et al. 2004, Kiørboe et al. 2003, Jürgens and Sala 2000).

\begin{tabular}{|c|c|c|c|c|c|c|}
\hline System & Location & $\begin{array}{l}\text { Abundance } \\
\left(\times 10^{6} \text { cells }\right. \\
\left.\mathrm{ml}^{-1}\right)\end{array}$ & $\begin{array}{l}\text { Ratio of } \\
\text { attached } \\
\text { bacteria (\%) }\end{array}$ & $\mid \begin{array}{l}\text { Density of } \\
\text { colonization } \\
\text { (cells particle-1) }\end{array}$ & OA type & Source \\
\hline \multirow{8}{*}{ Marine } & \begin{tabular}{|l} 
German \\
Wadden Sea \\
\end{tabular} & $1.0-2.9$ & $7-47$ & / & DAPI & \begin{tabular}{|l} 
Rink et al. \\
2008
\end{tabular} \\
\hline & NE Atlantic & $0.25-0.43$ & / & / & Macroaggregates & \begin{tabular}{|l|} 
Turley and \\
Mackie 1994 \\
\end{tabular} \\
\hline & \begin{tabular}{|l|} 
North \\
Atlantic \\
\end{tabular} & / & $0.1-4.4$ & $1.83-278 \times 10^{6}$ & Marine snow & $\begin{array}{l}\text { Alldredge et } \\
\text { al. 1986 }\end{array}$ \\
\hline & $\begin{array}{l}\text { NW } \\
\text { Mediterranean } \\
\text { Sea }\end{array}$ & / & \begin{tabular}{|l}
$9-32$ \\
$(3-30 \mathrm{~m})$ \\
$<10$ \\
$(>50 \mathrm{~m})$ \\
37.9 \\
$(250 \mathrm{~m})$ \\
14.9 \\
$(500 \mathrm{~m})$ \\
\end{tabular} & / & Alcidine orange & $\begin{array}{l}\text { Ghiglione et } \\
\text { al. } 2007\end{array}$ \\
\hline & $\begin{array}{l}\text { NW } \\
\text { Mediterranean } \\
\text { Sea } \\
\end{array}$ & / & $15 \pm 5$ & 1 & SYBR Green & $\begin{array}{l}\text { Mevel et al. } \\
2008\end{array}$ \\
\hline & $\begin{array}{l}\text { NW } \\
\text { Mediterranean } \\
\text { Sea }\end{array}$ & \begin{tabular}{|l}
$0.17(10 \mathrm{~m})$ \\
$0.17(30 \mathrm{~m})$ \\
$0.31(50 \mathrm{~m})$ \\
$0.34(80 \mathrm{~m})$ \\
$0.18(100 \mathrm{~m})$ \\
$0.10(150 \mathrm{~m})$ \\
\end{tabular} & $\begin{array}{l}9.1(10 \mathrm{~m}) \\
8.9(30 \mathrm{~m}) \\
9.4(50 \mathrm{~m}) \\
14.0(80 \mathrm{~m}) \\
11.1(100 \mathrm{~m}) \\
7.8(150 \mathrm{~m})\end{array}$ & / & SYBR Green I & $\begin{array}{l}\text { Ghiglione et } \\
\text { al. } 2009\end{array}$ \\
\hline & $\begin{array}{l}\text { Isefjord in } \\
\text { Denmark }\end{array}$ & / & $<25$ & / & SYBR Green I & $\begin{array}{l}\text { Tang et al. } \\
2006\end{array}$ \\
\hline & $\begin{array}{l}\text { Southern } \\
\text { California } \\
\text { Bight }\end{array}$ & / & $0.9-3.0$ & $1.25-1.69 \times 10^{6}$ & Marine snow & $\begin{array}{l}\text { Alldredge et } \\
\text { al. } 1986\end{array}$ \\
\hline
\end{tabular}




\begin{tabular}{|c|c|c|c|c|c|c|}
\hline & $\begin{array}{l}\text { Southern } \\
\text { California } \\
\text { Bight } \\
\end{array}$ & $0.1-1.7$ & / & / & Marine snow & $\begin{array}{l}\text { Simon et al. } \\
1990\end{array}$ \\
\hline & Monterey Bay & / & / & $3.2-5.4 \times 10^{8}$ & Giant aggregates & $\begin{array}{l}\text { Silver et al. } \\
1998\end{array}$ \\
\hline \multirow{8}{*}{$\begin{array}{l}\text { Estuaries } \\
\text { and } \\
\text { Rivers }\end{array}$} & $\begin{array}{l}\text { Columbia } \\
\text { River estuary } \\
(1995)\end{array}$ & $2.4(0.7-5.4)$ & 57.1 & / & DAPI & $\begin{array}{l}\text { Crump et al. } \\
\text { 1998, Crump } \\
\text { et al. } 1999\end{array}$ \\
\hline & $\begin{array}{l}\text { Columbia } \\
\text { River estuary } \\
(1997)\end{array}$ & $\begin{array}{l}3.3 \\
(0.1-12.6)\end{array}$ & 70.2 & / & DAPI & $\begin{array}{l}\text { Crump et al. } \\
\text { 1998, Crump } \\
\text { et al. } 1999\end{array}$ \\
\hline & River Danube & $0.78 \pm 0.08$ & $30.34 \pm 3.09$ & / & \begin{tabular}{|l|} 
Alcian Blue, \\
Coomassie \\
Brilliant Blue G- \\
250 \\
\end{tabular} & $\begin{array}{l}\text { Luef et al. } \\
2007\end{array}$ \\
\hline & River Danube & $0.09-2.3$ & 51.0 & / & SYBR Green I & \begin{tabular}{|l} 
Peduzzi and \\
Luef 2008
\end{tabular} \\
\hline & River Danube & $0.1-1.4$ & 9.5 & $8 \pm 3$ & DAPI & \begin{tabular}{|l|} 
Berger et al. \\
1996
\end{tabular} \\
\hline & Elbe Estuary & $5.0-50$ & / & / & DAPI & $\begin{array}{l}\text { Zimmerman } \\
\text { n-Timm et } \\
\text { al. } 1998\end{array}$ \\
\hline & Elbe Estuary & / & 75.0 & $0.3-2.5 \times 10^{6}$ & Alcian Blue & \begin{tabular}{|l|} 
Zimmerman \\
n 1997
\end{tabular} \\
\hline & River Elbe & $120-250$ & / & / & River snow & $\begin{array}{l}\text { Böckelmann } \\
\text { et al. } 2000\end{array}$ \\
\hline \multirow{6}{*}{$\begin{array}{l}\text { Deep } \\
\text { lakes }\end{array}$} & \begin{tabular}{|l} 
Lake \\
Constance
\end{tabular} & $0.002-0.016$ & / & / & Lake snow & $\begin{array}{l}\text { Schweitzer } \\
\text { et al. } 2001\end{array}$ \\
\hline & $\begin{array}{l}\text { Lake } \\
\text { Constance }\end{array}$ & / & 4.3 & $\begin{array}{l}4.04 \pm 3.08 \times 10^{6} \\
(6 \mathrm{~m}) \\
8.77 \pm 7.83 \times 10^{6} \\
(25 \mathrm{~m})\end{array}$ & $\begin{array}{l}\text { Macroaggregates } \\
(<3 \text { to } 20 \mathrm{~mm})\end{array}$ & $\begin{array}{l}\text { Grossart and } \\
\text { Simon } 1998\end{array}$ \\
\hline & $\begin{array}{l}\text { Lake } \\
\text { Constance }\end{array}$ & $1.2-23$ & / & / & Macroaggregates & $\begin{array}{l}\text { Grossart and } \\
\text { Simon } 1993\end{array}$ \\
\hline & $\begin{array}{l}\text { Lake } \\
\text { Constance }\end{array}$ & / & / & $0.5-2 \times 10^{6}$ & Macroaggregates & $\begin{array}{l}\text { Weiss et al. } \\
1996\end{array}$ \\
\hline & Lake Aydat & $0.533 \pm 0.124$ & 7.4 & / & TEP \& CSP & $\begin{array}{l}\begin{array}{l}\text { Lemarchand } \\
\text { et al. } 2006\end{array} \\
\end{array}$ \\
\hline & Lake Pavin & $0.099 \pm 0.036$ & 2.6 & / & TEP \& CSP & $\begin{array}{l}\text { Lemarchand } \\
\text { et al. } 2006\end{array}$ \\
\hline $\begin{array}{l}\text { Shallow } \\
\text { lakes }\end{array}$ & Lake Taihu & $3.6-32.4$ & 53.2 & $25.6 \pm 12.9$ & DAPI & Tang 2009 \\
\hline
\end{tabular}

Table 1. Abundances of aggregate-attached bacteria in various aquatic environments. 


\subsection{The abundance of OA-attached bacteria vs. free-living bacteria}

Bacteria are often highly enriched on aggregates as compared to the surrounding water (Alldredge et al. 1986, Becquevort et al. 1998). For example, in surface waters of Southern California Bight, the bacterial densities on sinking marine snow aggregates were $>2000$-fold higher than in the surrounding water (Ploug et al. 1999). In Lake Constance, the bacterial abundance on macroaggregates on a per volume basis was $\sim 10^{8} \mathrm{ml}^{-1}$, which is $100 \times$ higher than in the bulk water (Grossart and Simon 1993). Though the relative abundance of attached bacteria is lower than that of free-living bacteria in most aquatic systems, in many cases, the aggregates-attached bacteria are bigger and more active than free-living ones.

\section{The diversity of OA-attached bacteria}

\subsection{Morphological and phylogenetic diversity}

Organic aggregates are often colonized by bacteria. Bacteria can attached to newly formed aggregates within $5 \mathrm{~min}$, which made bacteria the pioneer colonizers of organic aggregates (Wörner et al. 2000). However, the morphological and phylogenetic diversity of OAattached bacteria are depend on the composition, age, size of aggregates and the physicochemical characteristics of the surrounding water.
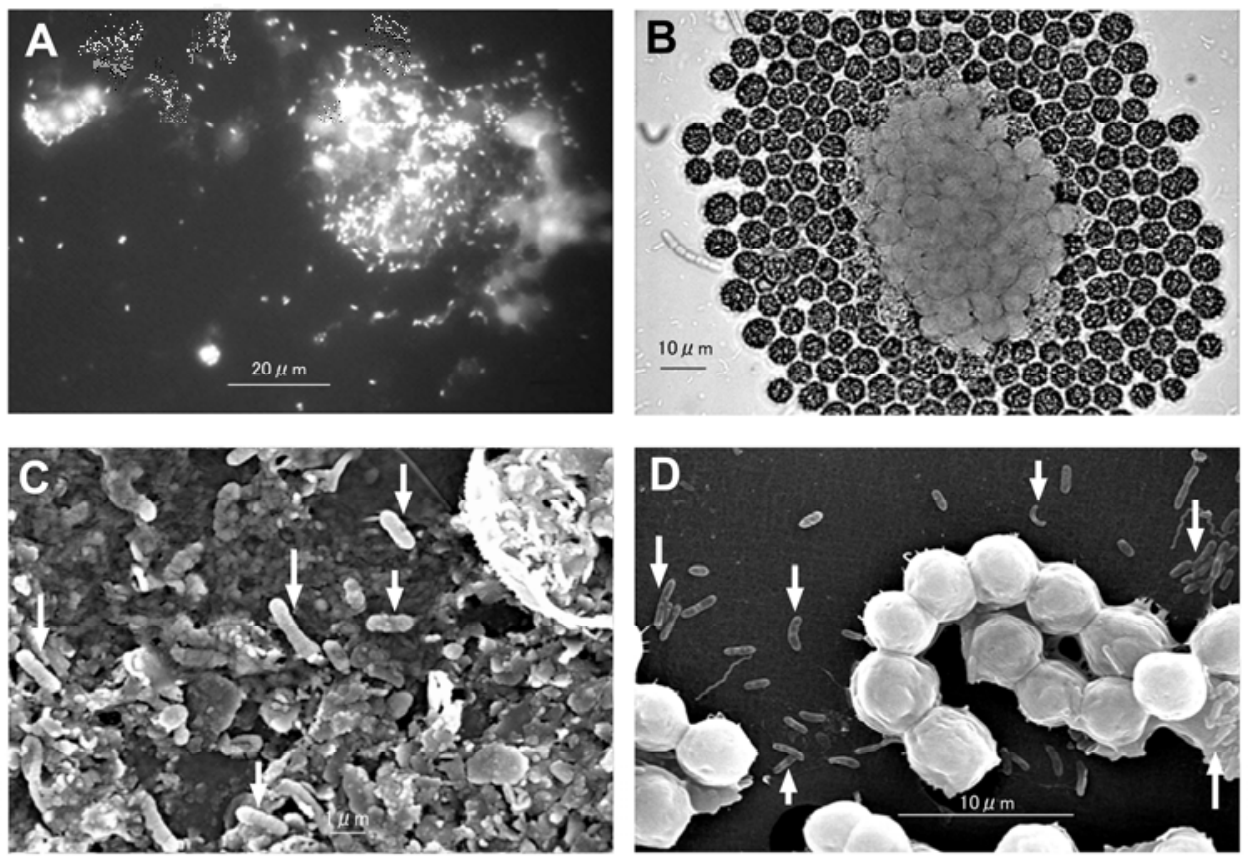

Fig. 2. Typical organic aggregates and the attached bacteria in Lake Taihu. (A) Microphotographs of DAPI-stained OA. The small bright dots represent bacteria. (B) Senescent Microcystis spp. aggregates surrounded by abundant bacteria (bright dots). Scanning electron micrographs of detritus-like aggregates (C) and phytodetrital aggregates (D). Small arrows indicate the presence of bacterial microcolonies. 
Generally, the composition of aggregates determines the morphological traits of OA and the attached bacteria. Observations of aggregates from coastal macrophyte-derived dissolved organic material by Alber \& Valiela (1994) showed that large numbers of rod-shaped bacteria attached to this kind of aggregates. Clear morphological differences can be observed on SEM micrographs for OA and OA-associated bacteria collected from the four sampling stations in Lake Taihu (Tang et al. 2009). Intense colonization of mucilage surrounding cyanobacterial cells was observed by DAPI stain and SEM (Fig. 2).

Newly formed aggregates are often colonized by small rod and coccidial-shaped bacteria, whereas older aggregates are colonized by filamentous bacteria $>0.5 \mu \mathrm{m}$ (ZimmermannTimm 2002). A 12-day observation of lab-made aggregates incubated in rolling cylinders showed both morphological and phylogenetic successions of the attached bacteria (Grossart and Simon 1998). During the first $2 \mathrm{~d}$, small aggregates $(<5 \mathrm{~mm} \varnothing)$ were dominated by cocci $(<1 \mu \mathrm{m})$. After 2 to $3 \mathrm{~d}$, larger rod bacteria were dominant and formed colonies. Filamentous or flagellated bacteria dominated after 5 to $7 \mathrm{~d}$. In the end, large aggregates $(>9 \mathrm{~mm} \varnothing)$ densely colonized by long and thick rods. During the experiment succession of $a-, \beta-$, and $\gamma^{-}$ proteobacteria were documented. And $\beta$-proteobacteria was usually dominant, particularly in aged aggregates (Grossart and Simon 1998).

The bacterial communities of macroscopic organic aggregates $(\geq 1 \mathrm{~mm}$ in diameter; from the river Weser) incubated in roller tanks were investigated by (Grossart and Ploug 2000). Using in situ hybridization, they found that the percentage of $a$ - and $\beta$-proteobacteria decreased from $13 \%$ and $33.7 \%$ to $2.6 \%$ and $9.0 \%$, respectively, whereas those of the filamentous $\gamma$ proteobacteria and Cytophaga increased from $31.9 \%$ to $50.4 \%$ and from $8.5 \%$ to $24.9 \%$, respectively, during the $14 \mathrm{~d}$ of incubation. The morphological and phylogenetic succession of aggregate-attached bacteria seems to be related to the interactions between bacteria and protozoans. The occurrence of high abundance of aggregate-attached filamentous bacteria, which are known to be a phenotypic response to protozoan grazing, can be the result of intense bacterial grazing by protists during a later stage (Grossart and Ploug 2000, Grossart and Simon 1998, Ploug and Grossart 2000, Simon et al. 2002, Jürgens and Matz 2002).

\subsection{The diversity of attached bacteria vs. free-living bacteria}

Difference between the community composition of particle-attached and free-living bacteria were found in most types of the aquatic systems, including Santa Barbara Channel (DeLong et al. 1993), Chesapeake Bay (Bidle and Fletcher 1995), Columbia River estuary (Crump et al. 1999), Mecklenburg Lake District (Allgaier and Grossart 2006), and other aquatic ecosystems (Kellogg and Deming 2009, Riemann and Winding 2001, Selje and Simon 2003; also Table 3).

Abundant researches carried out in marine and deep lakes showed that attached bacteria were always less abundant and less diverse but generally more active than free-living bacteria (Ghiglione et al. 2007, Grossart et al. 2003b, Simon et al. 2002). Using $16 S$ ribosomal desoxynucleic acid (rDNA) based clone library analysis, however, we found that in shallow productive eutrophic Lake Taihu, OA harbors diverse bacterial clusters (Tang et al. 2010, Tang et al. 2009). The bacterial diversity index of $S_{\text {Chao } 1}$ and Shannon index reached to $323.3 \pm$ 77.5 and 4.75 , respectively (Table 2). And there are no significant differences of diversity index between aggregates-attached and free-living bacterial communities (Unpublished data). These different patterns may reflect different shaping effects in different aquatic ecosystems on aggregates-attached bacterial communities. 
Use of DNA- and RNA-derived capillary electrophoresis single-strand conformation polymorphism fingerprinting, Ghiglione et al. (2009) examined the total and metabolically active communities of attached and free-living bacteria in the euphotic zone in the NW Mediterranean Sea. They found that $52-69 \%$ of the DNA-derived operational taxonomic units (OTUs) were common in both attached and free-living fractions, suggesting an exchange or co-occurrence between them. Even if colonization on and detachment of particles appear to be ubiquitous, most of the particulate organic carbon remineralisation appeared to be mediated by a rather low number of dominant active OTUs specialized in exploiting such specific microenvironment. In Lake Taihu, we also found some clues of exchanging among aggregates-attached, free-living and sediment-derived bacterial communities (Fig. 3). Comparative statistical analyses of the habitats of OA-associated bacteria highlight the potential ecological importance of the exchange between $\mathrm{OABC}$ and the surrounding planktonic community, because $41.5 \% \sim 78.8 \%$ of the sequences are related to freshwater habitats. However, we also found $21.2 \% \sim 58.5 \%$ of sequences closely related to ones previously found in soils, sludge, sediments and other habitats, indicating either the potential importance of allochthonous bacteria in OABC, or similar functions of these bacteria in multi-habitats (Rath et al. 1998, Simon et al. 2002).

\begin{tabular}{|l|l|l|l|l|l|l|l|l|}
\hline Sampling time & Clone library & Site & clones & SChao1 & OTUs & $H^{\prime}$ & RSI & C (\%) \\
\hline \multirow{5}{*}{ October 2006 } & $\mathrm{A}$ & $0^{\#}$ & 243 & $214.3 \pm 39.5$ & 104 & 4.53 & 45.4 & 74.1 \\
\cline { 2 - 9 } & $\mathrm{B}$ & $3^{\#}$ & 225 & $323.3 \pm 77.5$ & 106 & 4.31 & 19.5 & 65.3 \\
\cline { 2 - 9 } & $\mathrm{C}$ & $8^{\#}$ & 264 & $276.8 \pm 47.0$ & 127 & 4.75 & 43.5 & 68.6 \\
\cline { 2 - 9 } & $\mathrm{D}$ & $24^{\#}$ & 220 & $220.0 \pm 45.4$ & 96 & 4.40 & 36.1 & 71.4 \\
\hline \multirow{3}{*}{ Feburary 2007 } & $\mathrm{E}$ & $3^{\#}$ & 250 & $257.8 \pm 53.1$ & 109 & 4.58 & 48.3 & 72.4 \\
\cline { 2 - 9 } & $\mathrm{F}$ & $8^{\#}$ & 270 & $292.4 \pm 58.0$ & 119 & 4.56 & 35.8 & 70.7 \\
\hline \multirow{3}{*}{ May 2007 } & $\mathrm{G}$ & $3^{\#}$ & 264 & $323.0 \pm 70.1$ & 118 & 4.52 & 30.8 & 69.3 \\
\cline { 2 - 9 } & $\mathrm{H}$ & $8^{\#}$ & 269 & $268.2 \pm 46.0$ & 122 & 4.57 & 29.1 & 69.5 \\
\hline \multirow{4}{*}{ August 2007 } & $\mathrm{I}$ & $3^{\#}$ & 189 & $125.1 \pm 18.1$ & 81 & 4.37 & 46.3 & 77.8 \\
\cline { 2 - 8 } & $\mathrm{J}$ & $6^{\#}$ & 149 & $101.3 \pm 16.8$ & 65 & 4.15 & 35.6 & 77.9 \\
\cline { 2 - 8 } & $\mathrm{K}$ & $8^{\#}$ & 212 & $196.9 \pm 36.7$ & 98 & 4.57 & 48.5 & 72.6 \\
\cline { 2 - 8 } & $\mathrm{L}$ & $24^{\#}$ & 169 & $146.8 \pm 26.8$ & 79 & 4.39 & 48.8 & 71.6 \\
\hline
\end{tabular}

Table 2. Spatial and temporal dynamics of organic-aggregate-associated bacterial operational taxonomic units (OTUs) diversity in Lake Taihu, by means of the Chao1 richness estimator ( $\left.\mathrm{S}_{\mathrm{Chao1}}\right)$ and the reciprocal Simpson's dominance index (RSI). H': Shannon index; C: Coverage. Sampling sites as shown in Fig. 1.

\section{Dynamics of OA-attached bacterial communities}

\subsection{Spatial and temporal dynamics of OA-attached bacterial communities}

\subsubsection{Marine}

The structural composition of bacterial communities on marine snow appears to be dominated by the Cytophaga/Flavobacteria (i.e. Bacteroidetes) cluster and $\gamma$-proteobacteria. For example, DeLong et al. (1993) found that Cytophaga, Planctomyces, or $\gamma$-proteobacteria were the dominant bacterial clusters dwelled in the marine snow collected in the Santa Barbara Channel. In the Gulf of Trieste (northern Adriatic Sea), a high diversity of bacteria was found on marine snow with dominant phylotypes of the Cytophaga-Flavobacteria-Bacteroides 
lineage (Rath et al. 1998). On the basis of denaturing gradient gel electrophoresis (DGGE) of polymerase chain reaction (PCR)-amplified 16S rDNA fragments, Bidle \& Azam (2001) found that the bacterial community on aggregates of marine diatom detritus was dominated by $r$-proteobacteria and Sphingobacteria-Flavobacteria by comprising $65 \%$ and $25 \%$ of detected phylotypes, respectively. Other investigations on marine snow-attached bacterial communities in the Southern California Bight (Ploug et al. 1999), in the polar frontal zone of the Southern Ocean (Simon et al. 1999), in Schaproder Bodden (Hempel et al. 2008) and in German Wadden Sea (Rink et al. 2008) resulted in similar conclusion (Table 3).

\subsubsection{Estuaries and rivers}

The structure of aggregate-attached bacterial communities in river system, such as rivers and estuaries, is strikingly different from that on marine snow (Table 3). Using fluorescent in situ hybridization, Böckelmann et al. (2000), in the Elbe River of Germany, found that the bacterial aggregate community varied over the course of the year. During all seasons, $\beta$ proteobacteria constituted the numerically most important bacterial group constituting $\sim 54 \%$ of the total DAPI-stainable cells. They were characterized by short, rod-shaped bacteria (1 $\mu \mathrm{m}$ in length) showed typical polyalkanoate inclusion bodies and occurred as single cells or short chains, or globular microcolonies within the river snow community. In spring the community had been characterized by great bacterial diversity and by a high abundance of Cytophagae (up to $36 \%$ ). And the predominant bacterial morphotypes were long thin filaments (up to $40 \mu \mathrm{m}$ in length). In contrast, the number of filamentous CytophagaFlavobacteria decreased significantly in autumn and winter, with small, rod-shaped cells (0.5 $\times 1 \mu \mathrm{m})$. The percentage of $\gamma$-proteobacteria peaked at $26 \%$ in winter, which is significantly higher than that in autumn (14\%). Typical morphotypes within the $r$-proteobacteria were thick, rod-shaped bacteria $(1 \times 3 \mu \mathrm{m})$. The numbers of a-proteobacteria was around $24 \%$ in spring and $4 \%$ in summer, with rod-shaped $(0.5 \times 2 \mu \mathrm{m})$ and irregularly formed coccoid cells (diameter $1-1.5 \mu \mathrm{m}$ ). Planctomycetales and sulfate-reducing bacteria (SRB) were of lower significance and constituted 2 to $11 \%$ and 2 to $17 \%$, respectively.

Differences among the macroaggregates-attached bacterial communities in the limnetic, the brackish and the marine sections of the River Elbe, were reported by Simon et al. (2002). Using group-specific oligonucleotide probes, the authors found that in the limnetic section, $\beta$-proteobacteria and Cytophaga/Flavobacteria accounted for $20-40 \%$ and $25-36 \%$ of the DAPIstainable cells, respectively, in May, and $18-45 \%$ and $20 \%$, respectively, in October. In the brackish and marine section of the Elbe estuary, however, $\gamma$-proteobacteria largely dominated whereas $\beta$-proteobacteria constituted not more than $12 \%$. Salinity gradient seems to be one of the most important factors controlling the variations of the aggregate-attached bacterial communities from freshwater upstream to downstream estuary. With the increase in salinity, the $\beta$-proteobacteria was gradually replaced by $\gamma$-proteobacteria because salinity is a strong adaptive barrier for $\beta$-proteobacteria (Methé et al. 1998, Simon et al. 2002).

A 14-day observation of aggregates incubated in water samples of the river Weser, Northern Germany, in roller tanks revealed that the percentage of filamentous $r$-proteobacteria and Cytophaga increased from $31.9 \%$ to $50.4 \%$ and from $8.5 \%$ to $24.9 \%$, respectively, whereas those of $a$ - and $\beta$-proteobacteria decreased from $13 \%$ and $33.7 \%$ to $2.6 \%$ and $9.0 \%$, respectively (Grossart and Ploug 2000). The low percentage of $\beta$-proteobacteria presumably due to relative higher salinity $(<1 \%)$ of the incubation water. 


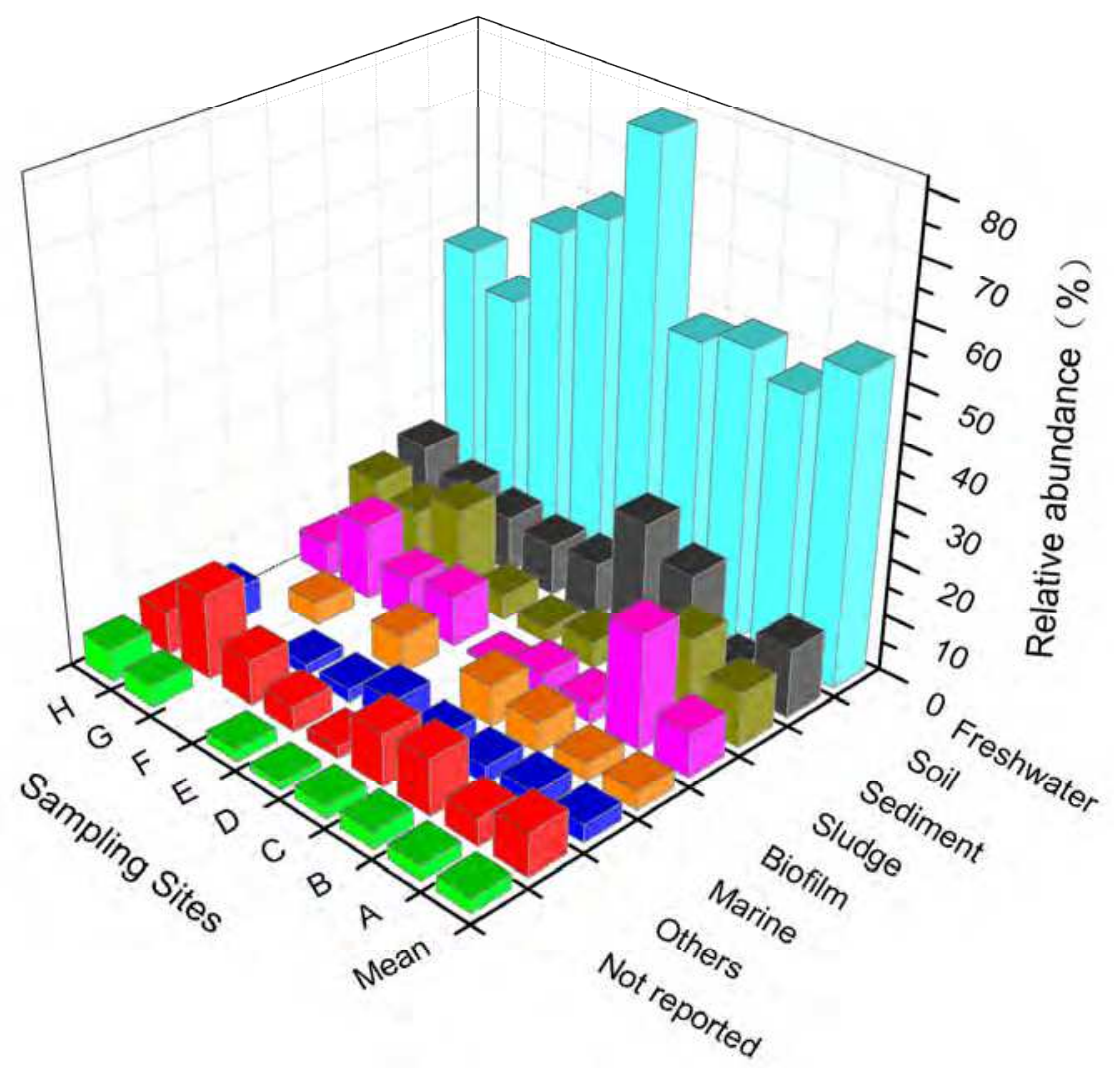

Fig. 3. Proportion of habitat affiliations of the sequences based on comparison of our $16 \mathrm{~S}$ rRNA clone library sequences with the closest relatives from the GenBank. A $\mathrm{H}$, represent different OA samples (detailed information is presented in Table 2); the bar labeled "Mean" gives the frequency distribution for all samples. Habitats affiliated with anaerobic swine lagoon, subsurface aquifer, wastewater, rumen fluid, human gut and fuel cell anode as well are included in 'Others'. 


\begin{tabular}{|c|c|c|c|c|c|c|c|c|}
\hline \multirow{2}{*}{ System } & \multirow{2}{*}{ Location } & \multirow{2}{*}{$\begin{array}{l}\text { Bacterial } \\
\text { type }\end{array}$} & \multicolumn{5}{|c|}{$\begin{array}{l}\text { Composition of associated bacterial } \\
\text { communities }(\%)\end{array}$} & \multirow{2}{*}{ Source } \\
\hline & & & $\beta$-prot. & a-prot. & $\gamma$-prot. & Bact. & Acti. & \\
\hline \multirow{4}{*}{ Marine } & \multirow{2}{*}{$\begin{array}{l}\text { German } \\
\text { Wadden Sea }\end{array}$} & Attached & $\mid \begin{array}{l}/ \\
15.3 \pm 11.4 \\
(2000) \\
8.2 \pm 5.1 \\
(2005)\end{array}$ & $\begin{array}{l}9.5 \pm 3.0 \\
(1999) \\
30.1 \pm 19.9 \\
(2000) \\
17.8 \pm 15.3 \\
(2005)\end{array}$ & \begin{tabular}{|l}
$16.5 \pm 2.3$ \\
$(1999)$ \\
$27.0 \pm 17.3$ \\
$(2000)$ \\
$28.8 \pm 9.8$ \\
$(2005)$
\end{tabular} & \begin{tabular}{|l}
$20.9 \pm 2.0$ \\
$(1999)$ \\
$27.6 \pm 16.4$ \\
$(2000)$ \\
$15.0 \pm 7.3$ \\
$(2005)$
\end{tabular} & / & $\begin{array}{l}\text { Rink et al. } \\
2008\end{array}$ \\
\hline & & $\begin{array}{l}\text { Free- } \\
\text { living }\end{array}$ & $\mid \begin{array}{l}/ \\
1.6 \pm 1.3 \\
(2000) \\
1.4 \pm 1.2 \\
(2005)\end{array}$ & $\begin{array}{l}13.8 \pm 4.0 \\
(1999) \\
7.9 \pm 7.2 \\
(2000) \\
7.2 \pm 4.1 \\
(2005)\end{array}$ & $\begin{array}{l}17.1 \pm 3.5 \\
(1999) \\
10.7 \pm 7.3 \\
(2000) \\
9.8 \pm 3.5 \\
(2005)\end{array}$ & $\begin{array}{l}19.2 \pm 3.6 \\
(1999) \\
13.6 \pm 7.2 \\
(2000) \\
11.5 \pm 5.2 \\
(2005)\end{array}$ & / & $\begin{array}{l}\text { Rink et al. } \\
2008\end{array}$ \\
\hline & $\begin{array}{l}\text { Northern } \\
\text { Adriatic Sea }\end{array}$ & Attached & / & 15.3 & 15.3 & / & / & $\begin{array}{l}\text { Rath et al. } \\
1998\end{array}$ \\
\hline & $\begin{array}{l}\text { Schaproder } \\
\text { Bodden }\end{array}$ & Attached & / & $3-17$ & / & $5-35$ & / & $\begin{array}{l}\text { Hempel et al. } \\
2008\end{array}$ \\
\hline \multirow{3}{*}{$\begin{array}{l}\text { Estuaries } \\
\text { and } \\
\text { Rivers }\end{array}$} & $\begin{array}{l}\text { Elbe River, } \\
\text { Germany }\end{array}$ & Attached & $\begin{array}{l}50 \pm 10 \sim \\
54 \pm 6\end{array}$ & $5-25$ & $\begin{array}{l}14 \pm 5 \sim \\
26 \pm 8\end{array}$ & / & & $\begin{array}{l}\text { Böckelmann } \\
\text { et al. } 2000\end{array}$ \\
\hline & $\begin{array}{l}\text { Elbe River, } \\
\text { Germany }\end{array}$ & Attached & 54 & / & / & 36 & / & $\begin{array}{l}\text { Böckelmann } \\
2001\end{array}$ \\
\hline & $\begin{array}{l}\text { Weser } \\
\text { estuary, } \\
\text { Germany }\end{array}$ & Attached & 10.0 & / & / & $28 \pm 8.9$ & / & $\begin{array}{l}\text { Selje and } \\
\text { Simon } 2003\end{array}$ \\
\hline \multirow{3}{*}{$\begin{array}{l}\text { Deep } \\
\text { lakes }\end{array}$} & \multirow{2}{*}{ Lake Aydat } & Attached & 30 & 11.7 & / & / & / & $\begin{array}{l}\text { Lemarchand } \\
\text { et al. } 2006\end{array}$ \\
\hline & & $\begin{array}{l}\text { Free- } \\
\text { living }\end{array}$ & 17.4 & 9.7 & / & / & / & $\begin{array}{l}\text { Lemarchand } \\
\text { et al. } 2006\end{array}$ \\
\hline & $\begin{array}{l}\text { Lake } \\
\text { Constance }\end{array}$ & Attached & $27-42$ & / & / & / & / & $\begin{array}{l}\text { Lemarchand } \\
\text { et al. } 2006\end{array}$ \\
\hline
\end{tabular}




\begin{tabular}{|c|c|c|c|c|c|c|c|c|}
\hline & $\begin{array}{l}\text { Lake } \\
\text { Constance }\end{array}$ & Attached & $\begin{array}{l}14.2 \pm 10.2 \\
(25 \mathrm{~m}) \\
54.0 \pm 5.9 \\
(50 \mathrm{~m}) \\
41.1 \pm 8.4 \\
(110 \mathrm{~m})\end{array}$ & $\begin{array}{l}10.5 \pm 7.9 \\
(25 \mathrm{~m}) \\
12.0 \pm 3.3 \\
(50 \mathrm{~m}) \\
2.7 \pm 1.4 \\
(110 \mathrm{~m})\end{array}$ & $\begin{array}{l}4.2 \pm 9.5 \\
(25 \mathrm{~m}) \\
1.9 \pm 0.7 \\
(50 \mathrm{~m}) \\
2.5 \pm 0.8 \\
(110 \mathrm{~m})\end{array}$ & 5.8 & / & $\begin{array}{l}\text { Schweitzer et } \\
\text { al. } 2001\end{array}$ \\
\hline & $\begin{array}{l}\text { Lake } \\
\text { Constance }\end{array}$ & $\begin{array}{l}\text { Free- } \\
\text { living }\end{array}$ & $\begin{array}{l}12.8 \pm 4.7 \\
(1996) \\
11.2 \pm 3.8 \\
(1997)\end{array}$ & $\begin{array}{l}4.3 \pm 4.6 \\
(1996) \\
3.9 \pm 2.5 \\
(1997)\end{array}$ & $\begin{array}{l}2.6 \pm 1.9 \\
(1996) \\
1.8 \pm 0.7 \\
(1997)\end{array}$ & / & / & $\begin{array}{l}\text { Zwisler et al. } \\
2003\end{array}$ \\
\hline & $\begin{array}{l}\text { Lake } \\
\text { Constance }\end{array}$ & Attached & $27-42$ & $11-25$ & $9-33$ & / & / & $\begin{array}{l}\text { Weiss et al. } \\
1996\end{array}$ \\
\hline \multirow{4}{*}{$\begin{array}{l}\text { Shallow } \\
\text { lakes }\end{array}$} & \multirow{2}{*}{ Lake Taihu } & Attached & 34.4 & 15.2 & 9.6 & 11.2 & 5.5 & $\begin{array}{l}\text { Tang et al. } \\
\text { 2010, Tang et } \\
\text { al. } 2009\end{array}$ \\
\hline & & $\begin{array}{l}\text { Free- } \\
\text { living }\end{array}$ & 10.8 & 5 & 7.4 & 2.7 & 52.1 & $\begin{array}{l}\text { Wu et al. } \\
2007 a\end{array}$ \\
\hline & \multirow{2}{*}{$\begin{array}{l}\text { Mecklenburg } \\
\text { Lake District }\end{array}$} & Attached & 3.2 & 8.1 & 3.2 & 24.2 & 1.6 & $\begin{array}{l}\text { Allgaier and } \\
\text { Grossart } 2006\end{array}$ \\
\hline & & $\begin{array}{l}\text { Free- } \\
\text { living }\end{array}$ & 10.4 & 8.3 & 0.7 & 14.6 & 44.4 & $\begin{array}{l}\text { Allgaier and } \\
\text { Grossart } 2006\end{array}$ \\
\hline
\end{tabular}

Table 3. Main phylogenetic composition of aggregate-attached and free-living bacterial communities in various aquatic environments. $\beta$-prot., a-prot., $\gamma$-prot., Bact. and Acti. represent $\beta$-proteobacteria, a-proteobacteria, $\gamma$-proteobacteria, Bacteroidetes, and Actinobacteria, respectively.

\subsubsection{Deep lakes}

Lake Constance is a typical deep large mesotrophic lake with maximum depth of $254 \mathrm{~m}$ and a surface area of $571 \mathrm{~km}^{2}$. The bacterial communities on lake snow aggregates in this lake have been intensively studied. Using FISH with rRNA-targeted oligonucleotides, Brachvogel et al. (2001) found that $\beta$-proteobacteria and Cytophaga/Flavobacteria dominated the bacterial community on microaggregates in Lake Constance, constituting 8 to $78 \%$ of the DAPI-stainable cells, which equals 14 to $82 \%$ of Bacteria. In contrast, a-proteobacteria was not detected at all. And $\gamma$-proteobacteria usually constituted only minor proportions except on zooplankton debris and on phytodetrital aggregates composed of Dinobryon spp. (Brachvogel et al. 2001). 
Schweitzer et al. (2001) examined the colonization of naturally formed lake snow aggregates and found that they are inhabited by a limited number of $\beta$ - and a-proteobacteria, which undergo a distinct succession. Detailed studies in Lake Constance, Lake Aydat and Lake Kinneret revealed that the bacterial communities on natural deep lake aggregates were dominated by few species of $\beta$-proteobacteria, Cytophaga/Flavobacteria and a-proteobacteria as well (Schweitzer et al. 2001, Grossart and Simon 1998, Simon et al. 2002, Lemarchand et al. 2006). This colonization pattern may reflect the similar adaptation of a specialized bacterial community to the unique environmental conditions on aggregates (Simon et al. 2002). The microbial community on lake snow was dominated by $\beta$-proteobacteria, especially during aggregate aging when filamentous and thus grazing resistant bacteria dominated (Grossart and Simon 1998). At earlier stages a-proteobacteria also comprised substantial fractions of the community. This community structure is similar to that of activated sludge flocs, suggesting that lake snow has a function comparable to that of activated sludge flocs in sewage treatment plants (Rath et al. 1998).

\subsubsection{Shallow eutrophic lakes}

Regional variability of OABC and diversity in Taihu were studied by amplified ribosomal DNA restriction analysis, and comparative analysis of eight large 16S rRNA clone libraries (Fig. 5). Our results demonstrate that OABC were numerically dominated by members of the $\beta$-proteobacteria $(34.4 \%)$, a-proteobacteria $(15.2 \%)$, Bacteroidetes $(11.2 \%)$, and Planctomycetes $(10.3 \%)$ groups. Clones affiliated with $\gamma$-proteobacteria, Actinobacteria, Acidobacteria, $\delta$ proteobacteria, Verrucomicrobia, Chloroflexi, Firmicutes, Gemmatimonadetes, Nitrospira, and candidate division OP10 were also found in low frequencies. The dominance of the Bacteroidetes group was related to algae-based aggregates.

The spatial and temporal variations of OABC were also determined by terminal restriction fragment length polymorphism (T-RFLP) analysis. A total of 246 T-RFs were detected from the studied sites, but only about 20 T-RFs were dominant, suggesting that specific microbial populations were adapted to the unique niche provided by the organic aggregates. Analysis of similarity (ANOSIM) revealed significant temporal shifts in OABC, and significant intralake heterogeneity.

In Mecklenburg Lake District, Allgaier and Grossart (2006) found that Bacteroidetes (24.2\%) is the most abundant phylum attached to particles, while Actinobacteria accounted for $44.4 \%$ of the free-living bacterial community. In Lake Taihu, Actinobacteria is the most abundant bacteria, representing $52.1 \%$ of the bacterioplankton community (Wu et al. 2007a).

\subsection{Environment factors structured the dynamics of OA-attached bacterial communities}

To our knowledge, environment factors structured the dynamics of attached bacterial communities have not been extensively studied, especially in shallow lakes. Allgaier and Grossart (2006) found that organic carbon (DOC), phytoplankton biomasses, and primary production have strong correlations with both particle-associated and free-living bacterial communities. In Lake Taihu, significant seasonal and station-dependent variations in OABC were found both in Meiliang Bay and in the lake center. Canonical correspondence analysis (CCA) demonstrated that temperature, dissolved oxygen, total suspended solids (TSS), nutrient levels, and some ions were significantly related to the spatio-temporal dynamics of OABC (Tang et al. 2010, Fig. 4). The findings add new insights into our understanding of the 
ecological importance of $\mathrm{OABC}$ in large shallow lakes, in particular the intra-lake heterogeneity, temporal evolution, and the interaction between $\mathrm{OA}$ and its surrounding water. On the overall, food web structures and water physicochemical conditions shape the aggregates-attached bacterial communities in aquatic systems. Obviously, attached bacterial colonization patterns reflect the different adaptation properties of the members of special bacteria to the given environmental conditions (Simon et al. 2002).

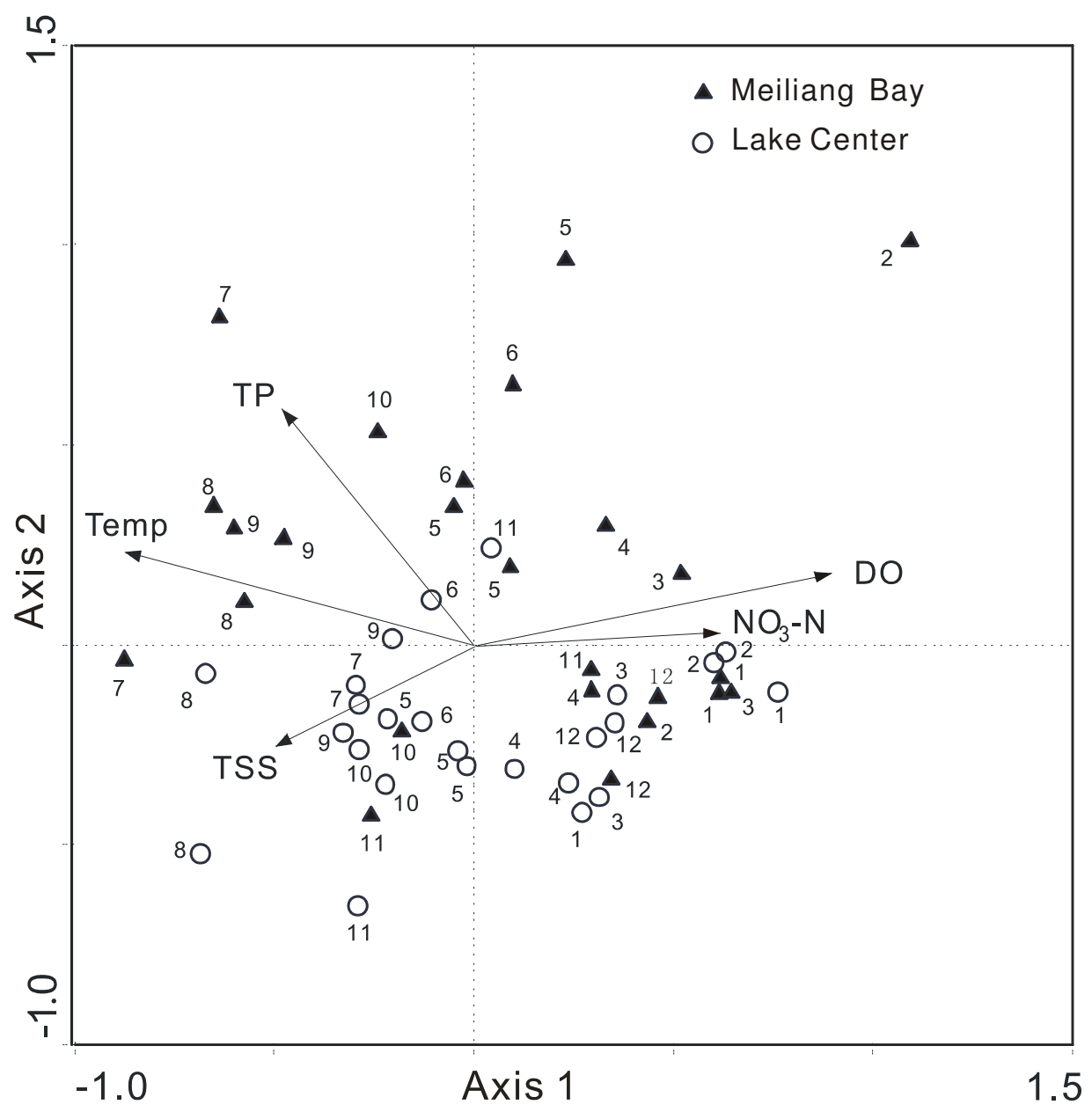

Fig. 4. Canonical Correspondence Analysis (CCA) biplot showed the impact of the statistically significant explanatory environmental variables on OABC in Meilaing Bay and Lake Center from May 2006 to May 2008. The matrices containing presence-absence of T-RFs were used as dependent variable. DO, TP, Temp, TSS, $\mathrm{NO}_{3}-\mathrm{N}$, refer to dissolved oxygen, total phosphorus, water temperature, total suspended solids and Nitrate, respectively. Months are represented by the numbers 1 (January) to 12 (December). 


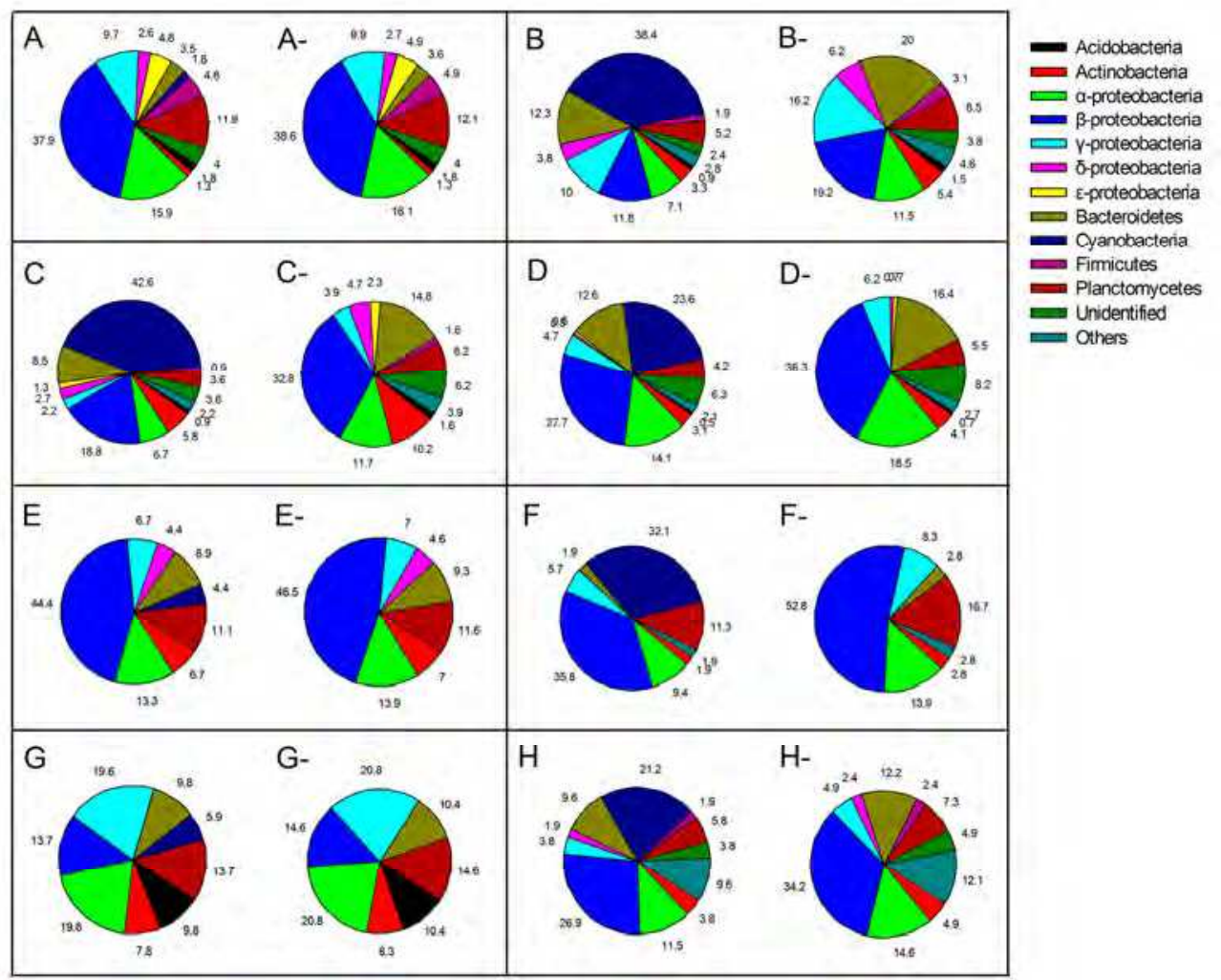

Fig. 5. Composition of associated bacterial communities. A $\mathrm{H}$, bacterial communities with Cyanobacteria; A- H-, bacterial communities without Cyanobacteria. Others include Gemmatimonadetes, Verrucomicrobia, OP10, Nitrospira and Chloroflexi. A H, represent different OA samples (detailed information is presented in Table 2).

\subsection{Ecology of main phyla of attached bacterial communities}

Studies have demonstrated that the $\beta$-proteobacteria, Bacteroidetes (formerly known as the Cytophaga-Flavobacteria-Bacteroides), $\quad r$-proteobacteria and a-proteobacteria are the most abundant bacterial cluster habitat on aggregates in most aquatic environments (see above). Despite the recognition that bacteria occupy a prominent role in aggregation processes and greatly impact biogeochemical processes, the bacterial taxa participating in these activities remain largely undescribed.

The Bacteroidetes comprise a large proportion of particle-associated bacteria (Table 3). Previous findings have highlighted the importance of Bacteroidetes during phytoplankton blooms (Eiler and Bertilsson 2004, Riemann and Winding 2001). In Lake Taihu, members of the Bacteroidetes formed a substantial component of the bacterial communities associated with algae-based OA. The high abundance of Bacteroidetes in the detritus-associated communities is related to their physiological characteristics. First, surface-dependent gliding motility is an important and widespread characteristic of these bacteria. Second, Bacteroidetes 
are chemoorganotrophic and efficiently degrade a variety of high molecular weight compounds such as protein, cellulose, pectin and chitin, and other polysaccharides (Kirchman 2002, DeLong et al. 1993). This finding might be related to their strong dependency on organic matter load or phytoplankton blooms

\section{Ecological significance of OA-attached bacteria}

Organic aggregates are involved in many ways in the nutrients cycling in aquatic ecosystems, such as decomposition of OA, cycling flux of particulate organic matter (POM), releasing of dissolved organic matter (DOM) and inorganic nutrients to the surrounding water. Bacteria clearly play an important role in most of the activities. POM solubilization, substrate hydrolysis and uptake, bacterial production, respiration and DOM release into the surrounding water are the major microbial processes.

\subsection{Bank of nutrients}

OA are composed of component particles consisting of living, senescent and dead algae, mainly diatoms in the ocean and Cyanobacteria in eutrophic lakes, but also of coccolithophorids, cysts of thecate dinoflagellates, phytodetritus, diatom frustules, bacteria, protozoans, zooplankton molts and carcasses, abandoned larvacean houses, pteropod webs, fecal pellets, macrophyte detritus, clay and silt minerals, calcite and other particles scavenged from surrounding water (Simon et al. 2002).

\begin{tabular}{|l|c|c|c|c|c|}
\hline \multicolumn{1}{|c|}{ Sampling site } & Site 10 & Site 3 & Site 8 & Site 14 & Mean \\
\hline OA abundance $/ \mathrm{mg}^{-1} \mathrm{~L}^{-1}$ & $48.49 \pm 41.17$ & $47.41 \pm 41.01$ & $58.65 \pm 41.92$ & $39.32 \pm 44.23$ & 48.47 \\
\hline $\mathrm{OA}-\mathrm{POM} / \mathrm{mg} \cdot \mathrm{g}^{-1}$ & $265.99 \pm 192.36$ & $208.64 \pm 119.44$ & $162.18 \pm 75.73$ & $248.83 \pm 161.36$ & 221.41 \\
\hline $\mathrm{OA}-\mathrm{C} / \mathrm{mg} \cdot \mathrm{g}^{-1}$ & $133.00 \pm 96.18$ & $104.32 \pm 59.72$ & $81.09 \pm 37.86$ & $99.52 \pm 58.65$ & 104.48 \\
\hline $\mathrm{OA}-\mathrm{N} / \mathrm{mg} \cdot \mathrm{g}^{-1}$ & $26.75 \pm 29.29$ & $19.88 \pm 10.56$ & $14.26 \pm 8.74$ & $18.51 \pm 12.79$ & 19.85 \\
\hline $\mathrm{OA}-\mathrm{P} / \mathrm{mg} \cdot \mathrm{g}^{-1}$ & $3.69 \pm 2.18$ & $2.3 \pm 0.93$ & $1.73 \pm 0.62$ & $2.48 \pm 1.23$ & 2.55 \\
\hline $\mathrm{C}_{\mathrm{OA}-\mathrm{N}} / \mathrm{TN}(\%)$ & 17.17 & 17.47 & 15.40 & 16.10 & 16.54 \\
\hline $\mathrm{C}_{\mathrm{OA}-\mathrm{P} / \mathrm{TP}(\%)}$ & 34.83 & 28.80 & 36.10 & 73.48 & 43.30 \\
\hline \multicolumn{1}{|c|}{$\mathrm{OA}-\mathrm{C}: \mathrm{N}: \mathrm{P}$} & $36: 7: 1$ & $45: 9: 1$ & $47: 8: 1$ & $40: 8: 1$ & $41: 8: 1$ \\
\hline
\end{tabular}

Table 4. Chemical composition of OA in different sampling sites (see Fig. 1) in Lake Taihu.

OA are rich of organic matter, for organic carbon constitutes 10 to $40 \%$ of the total aggregates dry weight in marine and up to $66 \%$ in limnetic aggregates. In marine systems, Grossart and Simon (1993) found that soluble reactive phosphorus (SRP) concentrations in the matrix water of aggregates were $>1,000$ times higher than in the surrounding water. Measurements of ammonia, nitrite, nitrate, and phosphate indicate significant differences in nutrient concentrations associated with OA from those of the surrounding water (Blackburn et al. 1998, Shanks and Trent 1979). But in shallow seas, estuaries and shallow lakes, macrophyte debris, resuspended minerals and inorganic particles also are important component of OA, so the relative percentage of organic matter are actually low in this kind of systems. According to our study, POM constitutes $10.45 \%$ of OA dry weight in Lake Taihu and the highest value $(75 \%)$ occur in summer during Cyanobacteria blooms. OA are also rich in other nutrients, such as nitrogen $(\mathrm{N})$ and phosphorus $(\mathrm{P})$, as OA-N and OA-P represented up to $16.54 \%$ and $43.30 \%$ of total $\mathrm{N}$ and $\mathrm{P}$ in water column in Lake Taihu (Table 
4). In Lake Kinneret, Israel, Grossart et al. (1998) revealed that aggregates with associated microorganisms are not only sites of vertical fluxes, centers of rapid and efficient recycling of POM, and a source of DOM, but also a potentially important food source for higher trophic levels. These findings indicate that organic aggregates are important sites for nutrient regeneration in aquatic systems and should be included in the conceptual framework of aquatic ecosystem studies.

\subsection{Bacterial production and respiration}

OA harbor a rich community of heterotrophic microbes, predominantly bacteria, which contribute only a small part of the total carbon of OA, but they are most important for OA decomposition (Bearon 2007, Grossart and Ploug 2000, Grossart and Simon 1998). Kirchman and Mitchell (1982) examined the abundance and heterotrophic uptake of bacteria attached to particulate matter suspended in five coastal ponds and two marshes, and found that although the number of particle-bound bacteria was $<10 \%$, these bacteria incorporated $>40 \%$ of $\left[{ }^{14} \mathrm{C}\right]$ glucose and $\left[{ }^{14} \mathrm{C}\right]$ glutamate in the systems. In laboratory conditions, Grossart et al. (2007) found that natural bacterial assemblages attached to model aggregates (agar spheres) had threefold higher cell-specific bacterial protein production (BPP) than their free-living counterpart. Eiler et al. (2006) demonstrated that phycosphere-associated bacteria contributed between 8.5 and $82 \%$ of total bacterial secondary production.

In some aquatic systems, the growth rate of associated bacteria were found only slightly higher or in the same range as rates of free-living ones, and the turnover time of OA particulate organic carbon (POC) estimated by OA-associated bacteria production is so long that months to years would be required. Hence, other processes such as enzymatic hydrolysis and respiration are considered to be major microbial processes in OA decomposition (Becquevort et al. 1998). For example, the protease activity of model aggregates-attached bacteria was 10-20 times higher than that of free-living bacteria (Grossart et al. 2007). The increased protease activity allow attached bacteria to quickly exploit aggregate resources, which may accelerate remineralization of marine snow and reduce the downward carbon fluxes (Grossart et al. 2007). In fact, high solubilization rates and net release of nutrients to the surrounding water, which exceeded greatly the carbon demand of OA-associated bacteria, were found to be more reasonable to explain the rapid decomposition of POC in OA (Grossart and Simon 1998).

\subsection{Nutrient recycling in shallow eutrophic lakes}

The aggregate microniche is recognized as an area of nutrient enrichment containing higher densities of both active and dead phototrophic and heterotrophic planktonic cells than in the surrounding water (Turley 2000). Because of distinct differences of hydrodynamic forcing among pelagic marine, deep lake, turbid riverine, and shallow lake systems, the origin, size, composition and destination of the aggregates and the major groups of microorganisms colonized on them, may exhibit pronounced differences. In Lake Taihu, OA were mainly come from the detritus of Cyanobacteria bloom and resuspended sediment, which dominate the whole lake nutrient cycling of Lake Taihu. In summer and in the phytoplankton dominated areas of Lake Taihu, the OA were contributed mainly by the detritus of phytoplankton, while in the period of wind-induced water turbulence, the OA were mainly contributed by resuspended inorganic sediment. 
There are significantly seasonal differences of the characteristics of OA in Lake Taihu, for the organic matter content of OA was significantly high during the summer of Cyanobacteria bloom than that in winter.

To investigate the relationship between wind induced turbulent and OA nutrient recycling in shallow eutrophic lake, in situ experiments were conducted in Meiliang Bay, located in the north part of Lake Taihu. The physical and chemical characteristics were continually monitored during a wind course (Fig. 6) one time per day, which continued for 10 days, and other water physical and chemical parameters were concomitantly monitored. OA abundance was significantly higher during wind period than calm stage and the maximum of $\mathrm{OA}$ abundance, which occurred the same day when wind speed was highest, was 29 times higher than that in the calm stage (Fig. 7). Although OA-C, OA-N and OA-P concentration were decreased during wind period the total OA C, N and P in water column were increased for the increased OA abundance (Fig. 8). Additionally, total suspended soil (TSS), total nitrogen (TN) and total phosphorus (TP) concentration during wind period were significantly higher than that of clam stage, but total dissolved phosphorus (TDP), total dissolved nitrogen (TDN) and soluble reactive phosphorus (SRP) were insignificantly different. During the wind period, OA alkaline phosphatase activity (OA-APA) and OA enzymatically hydrolysable phosphorus (OA-EHP) were both increased significantly, which accelerated organic phosphorous mineralization and SRP release (Fig. 9). The results indicate that SRP release induced by wind in shallow lakes may come from suspended matter, especially OA release rather than directly comes from sediment.

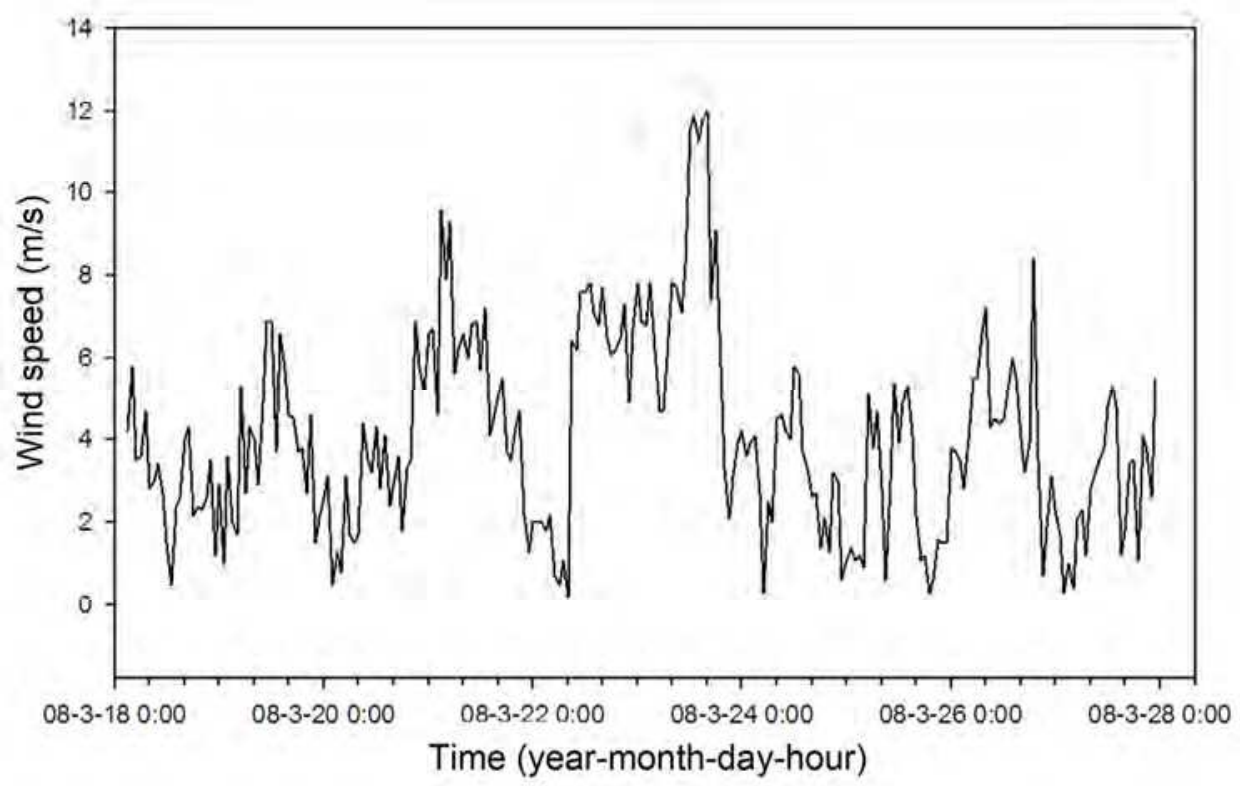

Fig. 6. Ten min averaged wind speed in the observation point during the study period. 


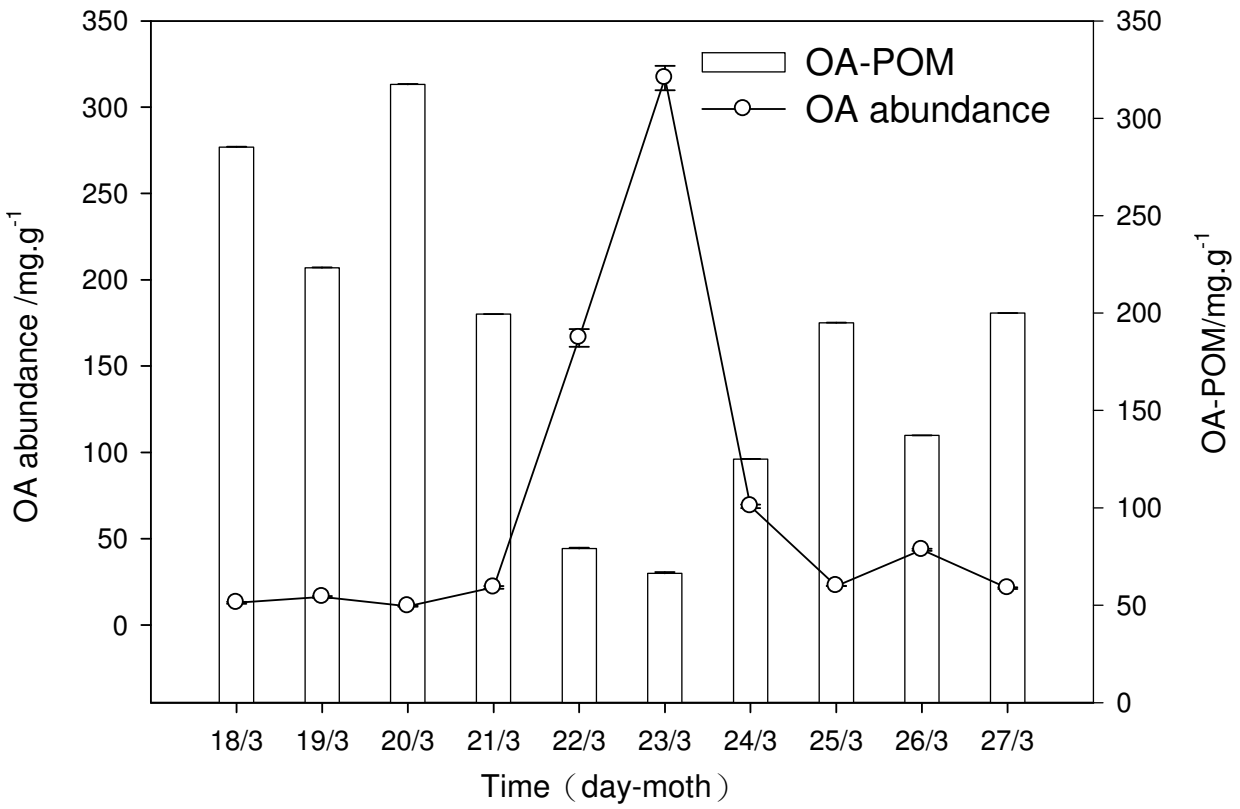

Fig. 7. Daily variability of OA abundance and OA-POM concentration during the 10-days observation in Meiliang Bay of Lake Taihu.

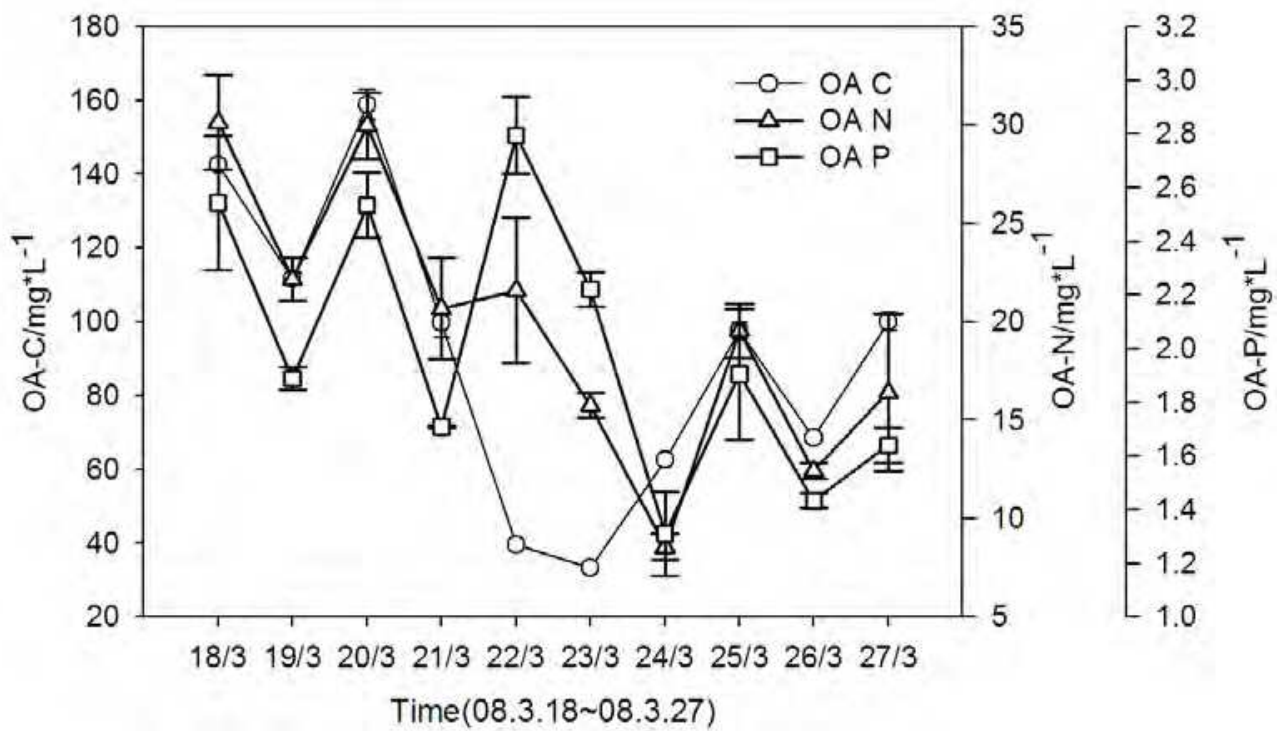

Fig. 8. Carbon, nitrogen, and phosphorous content of OA during wind period. 


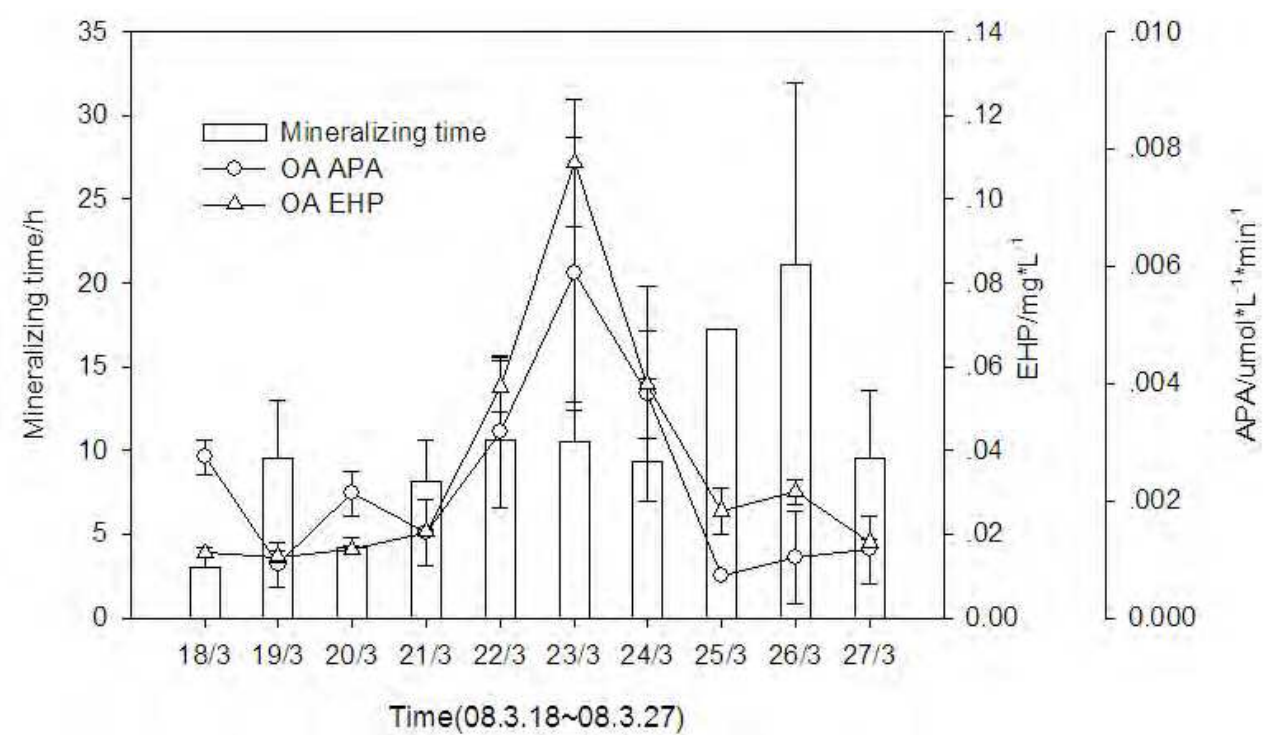

Fig. 9. Changes in OA-APA, OA-EHP concentration and OA-EHP mineralizing time.

\subsection{Cyanobacterial blooms}

During phytoplankton blooms in eutrophic lakes, primary productivity and its processing by the food web create a heterogeneous environment of particulate, colloidal, and dissolved organic matter in a continuum of size classes and concentrations. Blooms also have effect on the concentration and nutrient cycling of OA in water column (Turner 2002). Phosphorus is vital biogenic element in freshwater ecosystems such as lakes, reservoirs and rivers. Excessive $\mathrm{P}$ can eutrophicate freshwater bodies and further bring about harmful algal blooms, such as Cyanobacteria blooms in Lake Taihu (Paerl et al. 2011, Xu et al. 2010). The P-biogeochemical cycle plays crucial roles in freshwater ecosystems, and $\mathrm{P}$ release during the decomposition of cyanobacterial-bloom-formed OA is one of the most important processes involved.

To investigate $\mathrm{P}$ release during phytoplankton bloom, we carried out a stimulant experiment which focused on OA formation, decomposition and dissolved $\mathrm{P}$ release during cyanobacterial bloom in Lake Taihu. Considering the important role of turbulence, sediment and light on the decomposition, 6 treatments was set (Table 5). All treatments were conducted at a constant temperature $30 \pm 0.5^{\circ} \mathrm{C}$. The experiments lasted for 15 days, and the OA abundance, OA POM, Chl- $a$, SRP and TDP were measured on day 1, 2, 4, 6, 9, 12, 15.

\begin{tabular}{|l|l|l|l|}
\hline Treatments & Turbulence & Sediment & Light \\
\hline Treatment 1 (T1) & With & Without & Light \\
\hline Treatment 2 (T2) & Without & Without & Light \\
\hline Treatment 3 ( T3 ) & With & With & Light \\
\hline Treatment 4 (T4) & Without & With & Light \\
\hline Treatment 5 (T5) & With & With & Dark \\
\hline Treatment 6 (T6) & Without & With & Dark \\
\hline
\end{tabular}

Table 5. Different treatments of cyanobacterial decomposition experiments. 

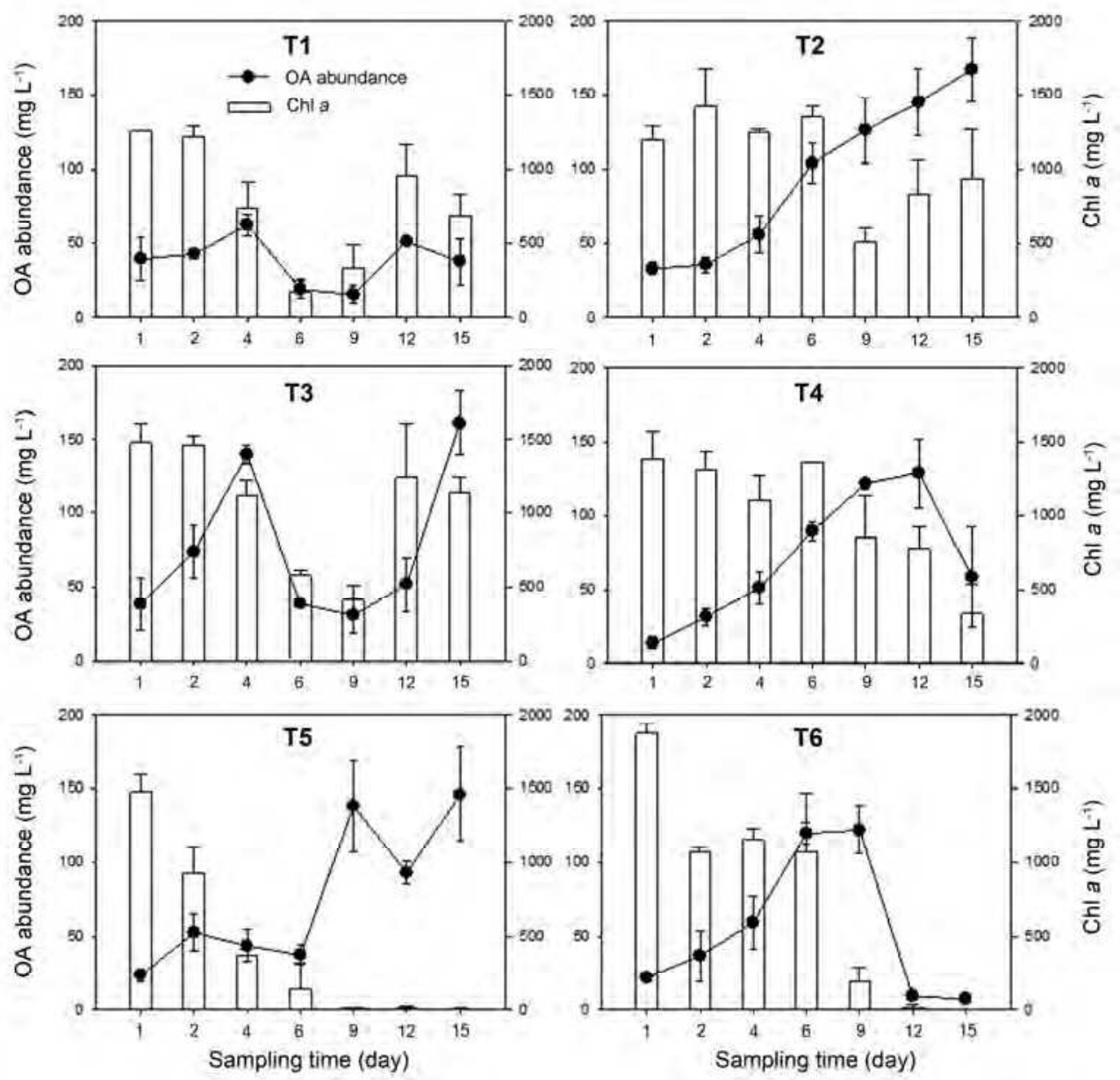

Fig. 10. Changes of OA abundance and the concentrations of Chl- $a$ during experiment period.

According to our study, the OA abundances were high during the study period, averaging $68.26 \mathrm{mg} \mathrm{L}^{-1}$ (Fig. 10) and organic matter constitutes $67.8 \%$ of OA dry weight, which is much higher than that of the average of Lake Taihu. The OA enzymatic hydrolysable phosphorus (OA-EHP) occupies 77\% of OA phosphorus (OA-P). This part of $\mathrm{P}$ can be hydrolyzed quickly by phosphatase to SRP, and released to surrounding water, which can be used directly by phytoplankton.

\section{Conclusions, open questions and prospects}

Given the facts that lakes have been described as early indicators of both regional and global environmental change (Williamson et al. 2008), and that lakes and other inland waters play 
a more critical role in the global carbon budget than previously recognized (Prairie et al. 2007), the role of microbes in these processes is of renewed interest (Newton et al. 2011). Based on the comparisons of abundance, diversity, community dynamic and potential function of aggregates-attached bacteria in marine, estuaries and rivers, deep lakes and shallow eutrophic lakes, we know that aggregates-attached bacteria are more abundant and show more phylogenetic diversity in more productive systems, such as rivers and shallow lakes. Already, the application of molecular techniques provides us with unprecedented access to the diversity and composition of OA-attached bacteria in time and space. However, the detailed ecological functions of these bacterial taxa participating in biogeochemical processes remain largely undescribed, especially in shallow eutrophic lakes. In our view, the major open issues, concerning the microbial ecology of attached bacteria in shallow eutrophic lakes, are the following: 1) Investigation of interaction between algae and their attached bacteria; 2) Identification and quantitative assessment of the role of attached bacteria in cyanobacterial decomposition and the regeneration of Cyanobacteria blooms; and 3) Examination of the importance of exchanging between aggregates-attached and freeliving bacterial communities. Further work, in particular on specific details with respect to the interaction among attached bacteria, free-living bacteria and algal blooms on both small and large temporal and spatial scales, will certainly improve our understanding of the microbial ecology of organic aggregates-attached bacteria in aquatic ecosystems, with respect to processes and mechanisms.

\section{Abbreviation}

ANOSIM - Analysis of similarity; BPP - bacterial protein production; CCA - canonical correspondence analysis; CSP - Coomassie-stained particles; DAPI - 4' 6-diamidino-2phenylindole dihydrochloride; DGGE - denaturing gradient gel electrophoresis; DNA desoxynucleic acid; EHP - enzymatically hydrolysable phosphorus; DOM - dissolved organic matter; FISH - fluorescent in situ hybridization; DOM - dissolved organic matter; OA - organic aggregates; OABC - organic-aggregate-associated bacterial communities; OTUs - operational taxonomic units; PCR - polymerase chain reaction; POC - particulate organic carbon; POM -particulate organic matter; rRNA - ribosomal ribonucleic acid; SEM scanning electron microscopy; SRB - sulfate-reducing bacteria; SRP - soluble reactive phosphorus; TEP - transparent exopolymer particles; TP - total phosphorus; T-RFLP terminal restriction fragment length polymorphism; TSS - total suspended solids

\section{Acknowledgment}

This work was supported by the National Basic Research Program of China (grant 2008CB418103) and National Water Pollution Control and Management of Science and Technology Major Projects (grant 2009ZX07101-013).

\section{References}

Alber, M. \& Valiela I. (1994) Production of microbial organic aggregates from macrophytederived dissolved organic material. Limnology and Oceanography, 39, 37-50. 
Alldredge, A., Cole J. J. \& Caron D. A. (1986) Production of heterotrophic bacteria inhabiting macroscopic organic aggregates (marine snow) from surface waters. Limnology and Oceanography, 31, 68-78.

Alldredge, A. L. \& Silver M. W. (1988) Characteristics, dynamics and significance of marine snow. Progress in Oceanography, 20, 41-82.

Allgaier, M. \& Grossart H.-P. (2006) Seasonal dynamics and phylogenetic diversity of freeliving and particle-associated bacterial communities in four lakes in northeastern Germany. Aquatic Microbial Ecology, 45, 115-128.

Azam, F. \& Richard A. L. (2001) Sea snow microcosms. Nature, 414, 495-498.

Böckelmann, U. 2001. Description and characterization of bacteria attached to lotic organic aggregates (river snow) in the Elbe River of Germany and the South Saskatchewan River of Canada. Berlin: der Technischen Universität Berlin.

Böckelmann, U., Manz W., Neu T. R. \& Szewzyk U. (2000) Characterization of the microbial community of lotic organic aggregates ('river snow') in the Elbe River of Germany by cultivation and molecular methods. FEMS Microbiology Ecology 33, 157-170.

Böckelmann, U., Manz W., Neu T. R. \& Szewzyk U. (2002) Investigation of lotic microbial aggregates by a combined technique of fluorescent in situ hybridization and lectinbinding-analysis. Journal of Microbiological Methods, 49, 75-87.

Bearon, R. N. (2007) A model for bacterial colonization of sinking aggregates. Bulletin of Mathematical Biology, 69, 417-431.

Becquevort, S., Rousseau V. \& Lancelot C. (1998) Major and comparable roles for free-living and attached bacteria in the degradation of Phaeocystis-derived organic matter in Belgian coastal waters of the North Sea. Aquatic Microbial Ecology, 14, 39-48.

Berger, B., Hoch B., Kavka G. \& Herndl G. J. (1996) Bacterial colonization of suspended solids in the River Danube. Aquatic Microbial Ecology, 10, 37-44.

Bidle, K. D. \& Azam F. (2001) Bacterial control of silicon regeneration from diatom detritus: Significance of bacterial ectohydrolases and species identity. Limnology and Oceanography, 46, 1606-1623.

Bidle, K. D. \& Fletcher M. (1995) Comparison of Free-Living and Particle-Associated Bacterial Communities in the Chesapeake Bay by Stable Low-Molecular-Weight Rna Analysis. Applied and Environmental Microbiology, 61, 944-952.

Blackburn, N., Fenchel T. \& Mitchell J. (1998) Microscale nutrient patches in planktonic habitats shown by chemotactic bacteria. Science, 282, 2254-2256.

Brachvogel, T., Schweitzer B. \& Simon M. (2001) Dynamics and bacterial colonization of microaggregates in a large mesotrophic lake. Aquatic Microbial Ecology, 26, 23-35.

Caron, D. A., Davis P. G., Madin L. P. \& Sieburth J. M. (1982) Heterotrophic bacteria and bacterivorous protozoa in oceanic macroaggregates. Science, 218, 795-797.

Crump, B. C., Armbrust E. V. \& Baross J. A. (1999) Phylogenetic analysis of particle-attached and free-living bacterial communities in the Columbia river, its estuary, and the adjacent coastal ocean. Applied and Environmental Microbiology 65, 3192-3204.

Crump, B. C., Baross J. A. \& Simenstad C. A. (1998) Dominance of particle-attached bacteria in the Columbia River estuary, USA. Aquatic Microbial Ecology, 14, 7-18. 
DeLong, E. F., Franks D. G. \& Alldredge A. L. (1993) Phylogenetic diversity of aggregateattached vs. free-living marine bacterial assemblages. Limnology and Oceanography, 38, 924-934.

Eiler, A. \& Bertilsson S. (2004) Composition of freshwater bacterial communities associated with cyanobacterial blooms in four Swedish lakes. Environmental Microbiology 6, 1228-1243.

Eiler, A., Olsson J. A. \& Bertilsson S. (2006) Diurnal variations in the auto- and heterotrophic activity of cyanobacterial phycospheres (Gloeotrichia echinulata) and the identity of attached bacteria. Freshwater Biology, 51, 298-311.

Ghiglione, J. F., Conan P. \& Pujo-Pay M. (2009) Diversity of total and active free-living vs. particle-attached bacteria in the euphotic zone of the NW Mediterranean Sea. FEMS Microbiology Letters, 299, 9-21.

Ghiglione, J. F., Mevel G., Pujo-Pay M., Mousseau L., Lebaron P. \& Goutx M. (2007) Diel and seasonal variations in abundance, activity, and community structure of particleattached and free-living bacteria in NW Mediterranean Sea. Microbial Ecology, 54, 217-231.

Grossart, H.-P. \& Ploug H. (2000) Bacterial production and growth efficiencies: Direct measurements on riverine aggregates. Limnology and Oceanography, 45, 436-445.

Grossart, H. P., Berman T., Simon M. \& Pohlmann K. (1998) Occurrence and microbial dynamics of macroscopic organic aggregates (lake snow) in Lake Kinneret, Israel, in fall. Aquatic Microbial Ecology, 14, 59-67.

Grossart, H. P., Hietanen S. \& Ploug H. (2003a) Microbial dynamics on diatom aggregates in Øresund, Denmark. Marine Ecology Progress Series, 249, 69-78.

Grossart, H. P., Kiørboe T., Tang K. \& Ploug H. (2003b) Bacterial colonization of particles: Growth and interactions. Applied and Environmental Microbiology, 69, 3500-3509.

Grossart, H. P., Kiørboe T., Tang K. W., Allgaier M., Yam E. M. \& Ploug H. (2006) Interactions between marine snow and heterotrophic bacteria: aggregate formation and microbial dynamics. Aquatic Microbial Ecology, 42, 19-26.

Grossart, H. P. \& Simon M. (1993) Limnetic marcoscopic organic aggregates (lake snow): Occurrence, characteristics, and microbial dynamics in Lake Constance. Limnology and Oceanography, 38, 532-546.

Grossart, H. P. \& Simon M. (1998) Bacterial colonization and microbial decomposition of limnetic organic aggregates (lake snow). Aquatic Microbial Ecology, 15, 127-140.

Grossart, H. P., Tang K. W., Kiørboe T. \& Ploug H. (2007) Comparison of cell-specific activity between free-living and attached bacteria using isolates and natural assemblages. FEMS Microbiology Letters 266, 194-200.

Hempel, M., Blume M., Blindow I. \& Gross E. M. (2008) Epiphytic bacterial community composition on two common submerged macrophytes in brackish water and freshwater. BMC Microbiology, 8, 10.

Jürgens, K. \& Matz C. (2002) Predation as a shaping force for the phenotypic and genotypic composition of planktonic bacteria. Antonie van Leeuwenhoek, 81, 413-434.

Jürgens, K. \& Sala M. M. (2000) Predation-mediated shifts in size distribution of microbial biomass and activity during detritus decomposition. Oikos, 91, 29-40. 
Kellogg, C. \& Deming J. (2009) Comparison of free-living, suspended particle, and aggregate-associated bacterial and archaeal communities in the Laptev Sea. Aquatic Microbial Ecology, 57, 1-18.

Kiørboe, T., Grossart H. P., Ploug H. \& Tang K. (2002) Mechanisms and rates of bacterial colonization of sinking aggregates. Applied and Environmental Microbiology, 68, 39964006.

Kiørboe, T., Grossart H. P., Ploug H., Tang K. \& Auer B. (2004) Particle-associated flagellates: swimming patterns, colonization rates, and grazing on attached bacteria. Aquatic Microbial Ecology, 35, 141-152.

Kiørboe, T. \& Jackson G. A. (2001) Marine snow, organic solute plumes, and optimal chemosensory behavior of bacteria. Limnology and Oceanography, 46, 1309-1318.

Kiørboe, T., Tang K., Grossart H. P. \& Ploug H. (2003) Dynamics of microbial communities on marine snow aggregates: Colonization, growth, detachment, and grazing mortality of attached bacteria. Applied and Environmental Microbiology, 69, 3036-3047.

Kirchman, D. \& Mitchell R. (1982) Contribution of particle-bound bacteria to total microheterotrophic activity in 5 ponds and 2 marshes. Applied and Environmental Microbiology, 43, 200-209.

Kirchman, D. L. (2002) The ecology of Cytophaga-Flavobacteria in aquatic environments. FEMS Microbiology Ecology 39, 91-100.

Lemarchand, C., Jardillier L., Carrias J. F., Richardot M., Debroas D., Sime-Ngando T. \& Amblard C. (2006) Community composition and activity of prokaryotes associated to detrital particles in two contrasting lake ecosystems. FEMS Microbiology Ecology, 57, 442-451.

Luef, B., Aspetsberger F., Hein T., Huber F. \& Peduzzi P. (2007) Impact of hydrology on freeliving and particle-associated microorganisms in a river floodplain system (Danube, Austria). Freshwater Biology, 52, 1043-1057.

Methé, B. A., Hiorns W. D. \& Zehr J. P. (1998) Contrasts between marine and freshwater bacterial community composition: Analyses of communities in Lake George and six other Adirondack lakes. Limnology and Oceanography, 43, 368-374.

Mevel, G., Vernet M., Goutx M. \& Ghiglione J. F. (2008) Seasonal to hour variation scales in abundance and production of total and particle-attached bacteria in the open NW Mediterranean Sea (0-1000 m). Biogeosciences, 5, 1573-1586.

Newton, R. J., Jones S. E., Eiler A., McMahon K. D. \& Bertilsson S. (2011) A guide to the natural history of freshwater lake bacteria. Microbiology and Molecular Biology Reviews, 75, 14-49.

Paerl, H. W. (1974) Bacterial uptake of dissolved organic matter in relation to detrital aggregation in marine and freshwater systems. Limnology and Oceanography, 19, 966-972.

Paerl, H. W. \& Prufert L. E. (1987) Oxygen-poor microzones as potential sites of microbial $\mathrm{N}_{2}$ fixation in nitrogen-depleted aerobic marine waters. Applied and Environmental Microbiology, 53, 1078-1087.

Paerl, H. W., Xu H., McCarthy M. J., Zhu G. W., Qin B. Q., Li Y. P. \& Gardner W. S. (2011) Controlling harmful cyanobacterial blooms in a hyper-eutrophic lake (Lake Taihu, China): The need for a dual nutrient (N \& P) management strategy. Water Research, 45, 1973-1983. 
Peduzzi, P. \& Luef B. (2008) Viruses, bacteria and suspended particles in a backwater and main channel site of the Danube (Austria). Aquatic Sciences, 70, 186-194.

Ploug, H. \& Grossart H. P. (2000) Bacterial growth and grazing on diatom aggregates: Respiratory carbon turnover as a function of aggregate size and sinking velocity. Limnology and Oceanography, 45, 1467-1475.

Ploug, H., Grossart H. P., Azam F. \& Jorgensen B. B. (1999) Photosynthesis, respiration, and carbon turnover in sinking marine snow from surface waters of Southern California Bight: implications for the carbon cycle in the ocean. Marine Ecology-Progress Series, 179, 1-11.

Prairie, Y. T., Cole J. J., Caraco N. F., McDowell W. H., Tranvik L. J., Striegl R. G., Duarte C. M., Kortelainen P., Downing J. A., Middelburg J. J. \& Melack J. (2007) Plumbing the global carbon cycle: Integrating inland waters into the terrestrial carbon budget. Ecosystems, 10, 171-184.

Qin, B. Q. 2008. Lake Taihu, China: dynamics and environmental change. Springer Netherlands.

Rath, J., Wu K. Y., Herndl G. J. \& DeLong E. F. (1998) High phylogenetic diversity in a marine-snow-associated bacterial assemblage. Aquatic Microbial Ecology, 14, 261-269.

Riemann, L. \& Winding A. (2001) Community dynamics of free-living and particleassociated bacterial assemblages during a freshwater phytoplankton bloom. Microbial Ecology, 42, 274-285.

Rink, B., Martens T., Fischer D., Lemke A., Grossart H. P., Simon M. \& Brinkhoff T. (2008) Short-term dynamics of bacterial communities in a tidally affected coastal ecosystem. FEMS Microbiology Ecology 66, 306-319.

Schweitzer, B., Huber I., Amann R., Ludwig W. \& Simon M. (2001) a- and $\beta$-Proteobacteria control the consumption and release of amino acids on lake snow aggregates. Applied and Environmental Microbiology, 67, 632-645.

Selje, N. \& Simon M. (2003) Composition and dynamics of particle-associated and free-living bacterial communities in the Weser estuary, Germany. Aquatic Microbial Ecology, 30, 221-237.

Shanks, A. L. \& Trent J. D. (1979) Marine snow - microscale nutrient patches. Limnology and Oceanography, 24, 850-854.

Silver, M. W., Coale S. L., Pilskaln C. H. \& Steinberg D. R. (1998) Giant aggregates: Importance as microbial centers and agents of material flux in the mesopelagic zone. Limnology and Oceanography, 43, 498-507.

Silver, M. W., Shanks A. L. \& Trent J. D. (1978) Marine snow: a microplankton habitat and source of smallscale patchiness in pelagic populations. Science, 201, 371-373.

Šimek, K., Hornak K., Jezbera J., Nedoma J., Vrba J., Straskrabova V., Macek M., Dolan J. R. \& Hahn M. W. (2006) Maximum growth rates and possible life strategies of different bacterioplankton groups in relation to phosphorus availability in a freshwater reservoir. Environmental Microbiology 8, 1613-1624.

Simon, M., Alldredge A. L. \& Azam F. (1990) Bacterial Carbon Dynamics on Marine Snow. Marine Ecology-Progress Series, 65, 205-211.

Simon, M., Glockner F. O. \& Amann R. (1999) Different community structure and temperature optima of heterotrophic picoplankton in various regions of the Southern Ocean. Aquatic Microbial Ecology, 18, 275-284. 
Simon, M., Grossart H. P., Schweitzer B. \& Ploug H. (2002) Microbial ecology of organic aggregates in aquatic ecosystems. Aquatic Microbial Ecology, 28, 175-211.

Smith, D. C., Simon M., Alldredge A. L. \& Azam F. (1992) Intense hydrolytic enzyme activity on marine aggregates and implications for rapid particle dissolution. Nature, 359, 139-141.

Tang, K. W., Grossart H. P., Yam E. M., Jackson G. A., Ducklowl H. W. \& Kiørboe T. (2006) Mesocosm study of particle dynamics and control of particle-associated bacteria by flagellate grazing. Marine Ecology-Progress Series, 325, 15-27.

Tang, X. 2009. Spatio-temporal dynamics of organic aggregates and its associated bacterial communities in a large, shallow, eutrophic lake (Lake Taihu, China). In Division of Lake Biology and Ecology. Nanjing: Nanjing Institute of Geography and Limnology, Chinese Academy of Sciences.

Tang, X., Gao G., Chao J., Wang X., Zhu G. \& Qin B. (2010) Dynamics of organic-aggregateassociated bacterial communities and related environmental factors in Lake Taihu, a large eutrophic shallow lake in China. Limnology and Oceanography, 55, 469-480.

Tang, X., Gao G., Qin B., Zhu L., Chao J., Wang J. \& Yang G. (2009) Characterization of bacterial communities associated with organic aggregates in a large, shallow, eutrophic freshwater lake (Lake Taihu, China). Microbial Ecology, 58, 307-322.

Turley, C. (2000) Bacteria in the cold deep-sea benthic boundary layer and sediment-water interface of the NE Atlantic. FEMS Microbiology Ecology, 33, 89-99.

Turley, C. \& Mackie P. (1994) Biogeochemical significance of attached and free-living bacteria and the flux of particles in the NE Atlantic Ocean. Marine Ecology-Progress Series, 115, 191-191.

Turner, J. T. (2002) Zooplankton fecal pellets, marine snow and sinking phytoplankton blooms. Aquatic Microbial Ecology, 27, 57-102.

Wörner, U., Zimmerman-Timm H. \& Kausch H. (2000) Succession of protists on estuarine aggregates. Microbial Ecology, 40, 209-222.

Weiss, P., Schweitzer B., Amann R. \& Simon M. (1996) Identification in situ and dynamics of bacteria on limnetic organic aggregates (lake snow). Applied and Environmental Microbiology, 62, 1998-2005.

Williamson, C. E., Dodds W., Kratz T. K. \& Palmer M. A. (2008) Lakes and streams as sentinels of environmental change in terrestrial and atmospheric processes. Frontiers in Ecology and the Environment, 6, 247-254.

Wu, Q. L., Zwart G., Wu J., Agterveld M., Liu S. \& Hahn M. W. (2007a) Submersed macrophytes play a key role in structuring bacterioplankton community composition in the large, shallow, subtropical Taihu Lake, China. Environmental Microbiology 9, 2765-2774.

Wu, Q. L. L., Chen Y. W., Xu K. D., Liu Z. W. \& Hahn M. W. (2007b) Intra-habitat heterogeneity of microbial food web structure under the regime of eutrophication and sediment resuspension in the large subtropical shallow Lake Taihu, China. Hydrobiologia, 581, 241-254.

Xu, H., Paerl H. W., Qin B., Zhu G. \& Gao G. (2010) Nitrogen and phosphorus inputs control phytoplankton growth in eutrophic Lake Taihu, China. Limnology and Oceanography, 55, 420-432. 
Zimmermann-Timm, H. (2002) Characteristics, dynamics and importance of aggregates in rivers - an invited review. International Review of Hydrobiology, 87, 197-240.

Zimmermann-Timm, H., Holst H. \& M“"1ler S. (1998) Seasonal dynamics of aggregates and their typical biocoenosis in the Elbe Estuary. Estuaries and Coasts, 21, 613-621.

Zimmermann, H. (1997) The microbial community on aggregates in the Elbe Estuary, Germany. Aquatic Microbial Ecology, 13, 37-46.

Zwisler, W., Selje N. \& Simon M. (2003) Seasonal patterns of the bacterioplankton community composition in a large mesotrophic lake. Aquatic Microbial Ecology, 31, 211-225. 


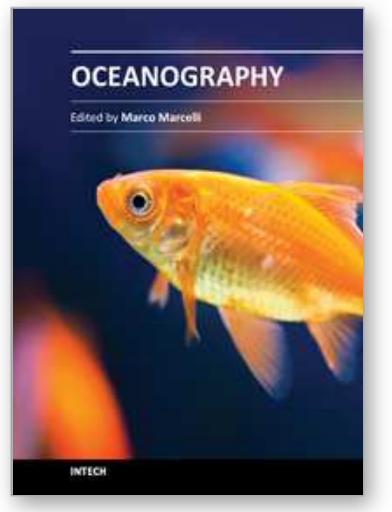

\author{
Oceanography \\ Edited by Prof. Marco Marcelli
}

ISBN 978-953-51-0301-1

Hard cover, 348 pages

Publisher InTech

Published online 23, March, 2012

Published in print edition March, 2012

How inappropriate to call this planet Earth when it is quite clearly Ocean (Arthur C. Clarke). Life has been originated in the oceans, human health and activities depend from the oceans and the world life is modulated by marine and oceanic processes. From the micro-scale, like coastal processes, to macro-scale, the oceans, the seas and the marine life, play the main role to maintain the earth equilibrium, both from a physical and a chemical point of view. Since ancient times, the world's oceans discovery has brought to humanity development and wealth of knowledge, the metaphors of Ulysses and Jason, represent the cultural growth gained through the explorations and discoveries. The modern oceanographic research represents one of the last frontier of the knowledge of our planet, it depends on the oceans exploration and so it is strictly connected to the development of new technologies. Furthermore, other scientific and social disciplines can provide many fundamental inputs to complete the description of the entire ocean ecosystem. Such multidisciplinary approach will lead us to understand the better way to preserve our "Blue Planet": the Earth.

\title{
How to reference
}

In order to correctly reference this scholarly work, feel free to copy and paste the following:

Xiangming Tang, Jianying Chao, Dan Chen, Keqiang Shao and Guang Gao (2012). Organic-AggregateAttached Bacteria in Aquatic Ecosystems: Abundance, Diversity, Community Dynamics and Function, Oceanography, Prof. Marco Marcelli (Ed.), ISBN: 978-953-51-0301-1, InTech, Available from: http://www.intechopen.com/books/oceanography/organic-aggregate-attached-bacteria-in-aquatic-ecosystemsabundance-diversity-community-dynamics-and

\section{INTECH}

open science | open minds

\section{InTech Europe}

University Campus STeP Ri

Slavka Krautzeka 83/A

51000 Rijeka, Croatia

Phone: +385 (51) 770447

Fax: +385 (51) 686166

www.intechopen.com

\section{InTech China}

Unit 405, Office Block, Hotel Equatorial Shanghai

No.65, Yan An Road (West), Shanghai, 200040, China 中国上海市延安西路65号上海国际贵都大饭店办公楼 405 单元

Phone: $+86-21-62489820$

Fax: $+86-21-62489821$ 
(C) 2012 The Author(s). Licensee IntechOpen. This is an open access article distributed under the terms of the Creative Commons Attribution 3.0 License, which permits unrestricted use, distribution, and reproduction in any medium, provided the original work is properly cited. 